\title{
Fission-track constraints on the thermal and tectonic evolution of the Apuseni Mountains (Romania)
}

\author{
Alexandre Kounov $\cdot$ Stefan M. Schmid
}

Received: 28 May 2011/ Accepted: 6 June 2012/Published online: 11 July 2012

(C) Springer-Verlag 2012

\begin{abstract}
New zircon and apatite fission-track (FT) data, including apatite thermal modelling, are combined with an extensive literature survey and reconnaissance-type structural fieldwork in the Eastern Apuseni Mountains. This leads to a better understanding of the complex structural and thermal history of a key area at the boundary between two megatectonic units in the Balkan peninsula, namely the Tisza and Dacia Mega-Units. Following Late Jurassic obduction of the Transylvanian ophiolites onto a part of the Dacia Mega-Unit, that is, the Biharia nappe system, both units were buried to a minimum of $8 \mathrm{~km}$ during late Early Cretaceous times when these units were underthrust below the Tisza Mega-Unit consisting of the present-day Codru and Bihor nappe systems. Tisza formed the upper plate during Early Cretaceous ('Austrian') east-facing orogeny. Turonian to Campanian zircon FT cooling ages (95-71 Ma) from the Bihor and Codru nappe systems and the Biharia and Baia de Arieş nappes (at present the structurally lowest part of the Dacia Mega-Unit) record exhumation that immediately followed a second Cretaceous-age (i.e. Turonian) orogenic event. Thrusting during this overprinting event was NW-facing and led to the overall geometry of the present-day nappe stack in the Apuseni Mountains. Zircon FT ages, combined with thermal modelling of the apatite FT data, show relatively rapid post-tectonic cooling induced by a third shortening pulse during the latest Cretaceous ('Laramian' phase), followed
\end{abstract}

\footnotetext{
A. Kounov $(\bowtie) \cdot$ S. M. Schmid

Institute of Geology and Paleontology, Basel University,

4056 Basel, Switzerland

e-mail: a.kounov@unibas.ch

Present Address:

S. M. Schmid

Institute of Geophysics, ETH, 8092 Zürich, Switzerland
}

by slower cooling across the $120^{\circ}-60^{\circ} \mathrm{C}$ temperature interval during latest Cretaceous to earliest Paleogene times (75-60 Ma). Cenozoic-age slow cooling (60-40 Ma) was probably related to erosional denudation postdating 'Laramian' large-scale updoming.

Keywords Apuseni Mountains - Fission-track analysis · Tisza $\cdot$ Dacia $\cdot$ Transylvanian ophiolites

\section{Introduction}

The Apuseni Mountains occupy an area of particular importance within the Carpathian part of the AlpineMediterranean orogen (Fig. 1). Their location is unique in the sense that the area provides outcrops of the boundary area between the Tisza and Dacia Mega-Units. These units represent far travelled continental blocks of still somewhat enigmatic origin with Adriatic and European affinities, respectively, and a branch of Neotethys containing predominantly Jurassic-age ophiolites outcropping in the South Apuseni ('Metaliferi') Mountains and buried underneath the Transylvanian Basin (e.g. Burchfiel 1980; Săndulescu 1984, 1994; Csontos and Vörös 2004; Haas and Pero 2004; Schmid et al. 2008; Ustaszewski et al. 2008).

While the geodynamic views regarding the Miocene tectonic evolution of the Tisza and Dacia continental blocks, largely inspired by the pioneering work of Balla (1987), converge to a certain extent amongst the various authors, there is still considerable controversy regarding the early Alpine tectonic evolution of the area during Jurassic and Cretaceous times. This is largely due to substantial latest Cretaceous to Cenozoic tectonic overprint, the considerable lack of geochronological constraints and the extremely poor outcrop conditions outside the area of 


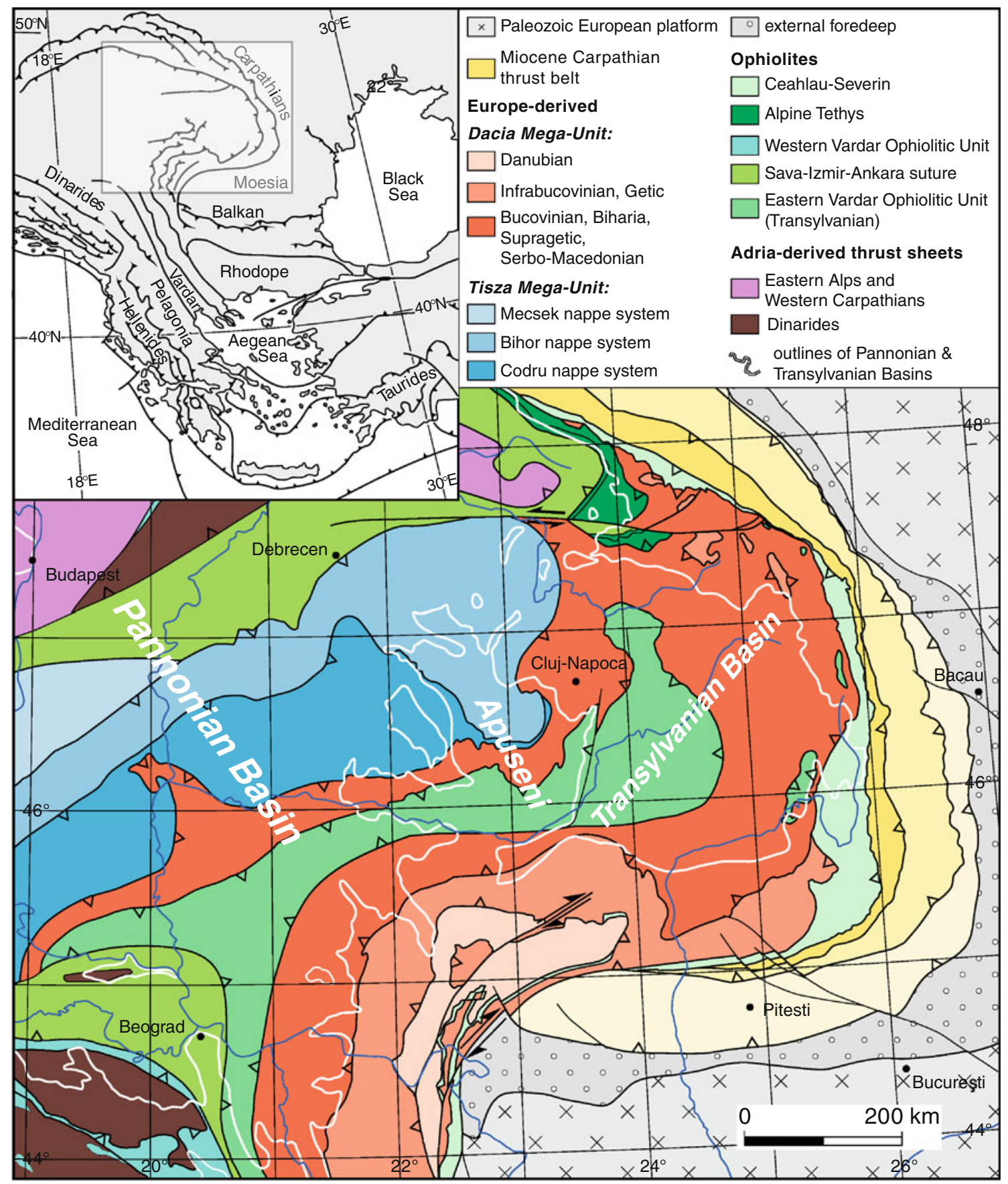

Fig. 1 Major tectonic units of the Carpathians (from Schmid et al. 2008). Top left inset shows a tectonic sketch map of the Balkan Peninsula

the Apuseni Mountains. Major disagreement concerns the paleogeographic and tectonic position of the South Apuseni-Transylvanian Neotethys-derived ophiolites and the location of the boundary between the Tisza and Dacia Mega-Units (Csontos and Vörös 2004; Schmid et al. 2008). The Biharia nappe system, which presently occupies the tectonically highest position amongst the continent-derived nappe pile of the Apuseni Mountains (Fig. 2), was considered as an integral part of the Tisza Mega-Unit by most authors (e.g. Csontos and Vörös 2004). Recently, however, it was attributed to the Dacia Mega-Unit (Fig. 1; Schmid et al. 2008) on the grounds that the Biharia nappe system apparently has been involved in Early Cretaceous E-facing nappe stacking, which is typical for the East Carpathian basement nappes constituting the Dacia Mega-Unit; only during the Late Cretaceous, the Biharia nappe system became involved in top-NW thrusting. The primary reason for the uncertainties leading to different views (e.g. 


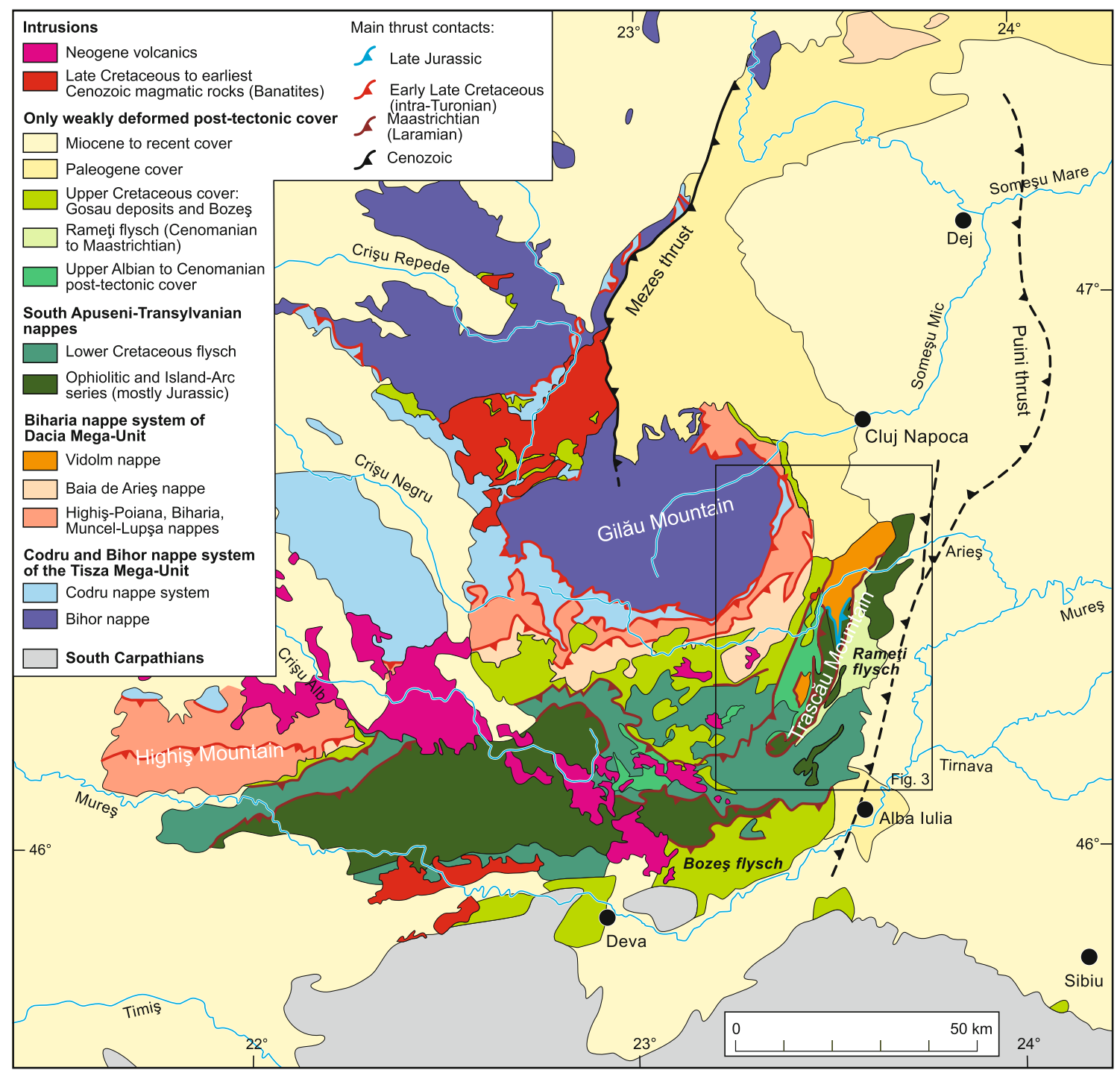

Fig. 2 Geological map of the Apuseni Mountains

Săndulescu 1984, 1994; Pană and Erdmer 1994; Pană 1998; Dallmeyer et al. 1999; Ellero et al. 2002; Schmid et al. 2008; Schuller et al. 2009) is that the deformation events that shaped the Apuseni Mountains are poorly studied in terms of timing and kinematics of deformation. Moreover, the regional literature quotes an immense number of small nappes that have been defined on purely lithological and/or stratigraphical principles and largely without a detailed study regarding mutual tectonic contacts and kinematics of deformation (e.g. Bleahu et al. 1981; Balintoni 1994).

This contribution focuses on low-temperature thermochronology. The continental and oceanic units that constitute the nappe pile of the Apuseni Mountains only experienced deformation and metamorphism at moderate temperatures since the end of the Palaeozoic. Hence, fission-track analysis, in combination with field studies and literature data, serves well for revealing the geodynamic evolution of the area. This paper complements a recent study focussing on thermochronology at very low temperatures (Merten et al. 2011) and presents a zircon and apatite fission-track study of preMesozoic basement rocks and Neotethys ophiolites from all major tectonic units in the south-eastern part of the Apuseni Mountains including Jurassic and Cretaceous sedimentary cover sequences. By doing this, we aim to define the relative position of the major tectonic units during early Alpine orogeny. Through combining the zircon fission-track ages with modelling of apatite data, we define periods of heating and cooling related to successive tectonic pulses and/or magmatic activities in the area. 


\section{Regional geology}

\section{General overview}

The Apuseni Mountains are located between the Pannonian and Transylvanian Cenozoic basins. They expose, amongst other units, the largest outcropping part of the Tisza MegaUnit (Figs. 1, 2). A stack of several nappe sequences formed in response to continental collision, which followed obduction and/or closure of various branches of the Neotethys and/or Alpine Tethys (e.g. Săndulescu 1994; Haas and Pero 2004; Csontos and Vörös 2004; Schmid et al. 2008). The northern Apuseni Mountains are composed of a stack of continent-derived basement and/or cover nappes, namely from bottom to top, the Bihor, Codru and Biharia nappe systems. Within the working area (Fig. 3), the Biharia nappe system can be subdivided into three thrust sheets that are, from bottom to top, the Biharia nappe, the Baia de Arieş nappe and the Vidolm nappe (Săndulescu 1984). The last two are also referred to as Southern Gneissic Terrane by Pană et al. (2002). All three nappe systems are unconformably covered by post-tectonic deposits, most importantly by late Albian to Cenomanian clastic sediments and by Turonian to Maastrichtian Gosau sediments (Figs. 2, 3; Săndulescu 1984; Balintoni 1994; Schuller 2004; Schuller et al. 2009). These post-tectonic deposits were subsequently affected by only moderate shortening in Maastrichtian and Paleogene times (Schuller 2004; Merten et al. 2011).

All three nappe systems include crystalline basement rocks of Pre-Cambrian-Cambrian protolith age, metamorphosed and deformed under amphibolite facies conditions prevailing during Variscan orogeny (e.g. Bleahu et al. 1981; Dimitrescu 1985; Kräutner 1993; Balintoni 1994, 1997; Dallmeyer et al. 1999; Pană et al. 2002; Balintoni et al. 2010). This basement has been intruded by syn- to post-Variscan granitoids and was transgressively covered by a Permian to Lower Cretaceous sedimentary sequence (Pană et al. 2002; Balintoni et al. 2009, 2010). In the studied area of the Gilău and Trascău Mountains, these three nappe systems predominantly consist of pre-Permian crystalline basement rocks, but metasandstones and conglomerates and low-grade marbles (e.g. Vulturese-Belioara marbles) of suspected Permo-Mesozoic age are also found (Fig. 3). The high-grade pre-Mesozoic basement rocks of the Biharia nappe and parts of the Codru nappe system, and in part their Permo-Triassic cover, are strongly overprinted by Alpine-age retrograde greenschist-facies metamorphism and deformation within a broad shear zone, referred to as Highis-Biharia Shear Zone in the literature (Pană and Erdmer 1994; Pană 1998; Dallmeyer et al. 1999).

The structurally highest unit amongst these continentderived nappes, the Vidolm nappe of the Biharia nappe system (Figs. 2, 3), is overlain by the ophiolite-bearing South Apuseni-Transylvanian nappes that are also found in the subsurface of the Transylvanian Basin and in the internal Eastern Carpathians (e.g. Săndulescu et al. 1981; Schmid et al. 2008; Hoeck et al. 2009). In the Apuseni Mountains, the Transylvanian nappes include two types of oceanic basement considered to be derived from a branch of Neotethys: (1) calc-alkaline volcanic and intrusive rocks representing an island arc exposed in the Trascau Mountains, that is, in the investigated area (Fig. 3) and (2) a MORB-type ophiolitic suite exposed further to the west in the Mures Valley (Fig. 2). While these two series were previously believed to represent a single magmatic sequence (e.g. Rădulescu and Săndulescu 1973), they are nowadays interpreted as petrogenetically unrelated: the island-arc magmatic activity was installed on previously formed MORB-type oceanic lithosphere during intra-oceanic subduction (Saccani et al. 2001; Bortolotti et al. 2002; Nicolae and Saccani 2003). Such a two-stage evolution is supported by the available biostratigraphic and $\mathrm{K} / \mathrm{Ar}$ radiometric data (Nicolae et al. 1992). The MORB-type ophiolites yield a minimum protolith age of $168 \pm 5 \mathrm{Ma}$ (K/Ar whole rock radiometric data, Nicolae et al. 1992). The overlying radiolarian cherts are of Callovian to Oxfordian age (165-155 Ma, Lupu et al. 1995), that is, very similar to the ages of calc-alkaline rocks that vary between 160 and $155 \mathrm{Ma}$ (Nicolae et al. 1992) and to an age around 159-160 Ma for the mineralization of a plagiogranite intruding the ophiolites (Zimmerman et al. 2008). In the working area, an Upper Oxfordian to Lower Cretaceous (Valanginian) carbonate platform was installed on the calcalkaline volcanic suite ('Oxfordian to Valanginian carbonates’ of Fig. 3; Săsăran 2005; Bucur and Săsăran 2005). Lower Cretaceous flysch overlies this carbonate succession (Figs. 2, 3).

\section{Jurassic evolution}

The first Alpine tectonic event in the area led to the tectonic emplacement of the South Apuseni-Transylvanian ophiolites (briefly referred to as 'Transylvanian ophiolites' hereafter) onto continental basement of the Biharia nappes system (e.g. Bleahu et al. 1981; Schmid et al. 2008). Upper Jurassic to Lower Cretaceous near-shore carbonates laterally grading into carbonate turbidites and pelagic limestones stratigraphically overlie island-arc volcanics of the Transylvanian ophiolites, as well as continental basement and the suspected Mesozoic cover of the Vidolm nappe (Fig. 3; Săsăran 2005; Bucur and Săsăran 2005). This implies tectonic emplacement of the Transylvanian ophiolites onto the distal continental margin in Late Oxfordian times, that is, before deposition of these unconformably overlying carbonates (Csontos and Vörös 2004; Schmid 


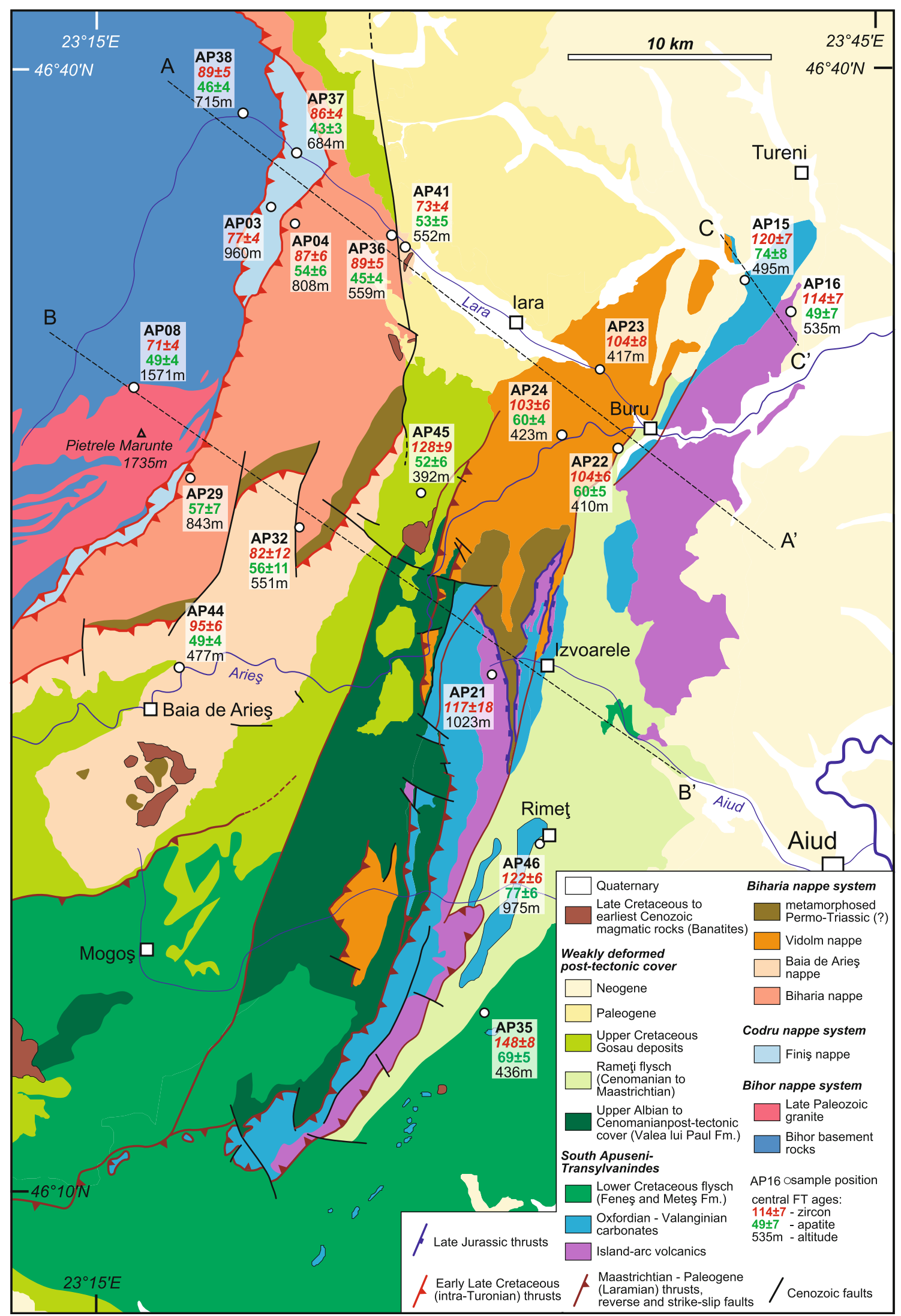

Fig. 3 Geological map of the East Apuseni Mountains with sample location and FT ages. Lines $A A^{\prime} B B^{\prime}$ and $C C^{\prime}$ are the sections in Fig. 4 
et al. 2008). However, there is no general agreement yet regarding the attribution of the Transylvanian ophiolites to either the Alpine Tethys (e.g. Săndulescu 1994; Schuller et al. 2009) or, alternatively, a branch of Neotethys (e.g. Csontos and Vörös 2004; Schmid et al. 2008). Also, there is no consensus about the derivation of the Biharia nappe system that tectonically underlies the Transylvanian ophiolites. Most authors regard the Biharia nappe system as an integral part of the Tisza Mega-Unit. Schmid et al. (2008), however, attributed the Biharia nappe system to the Dacia Mega-Unit over which the Transylvanian ophiolites were obducted in the Late Jurassic. According to these authors, the contact at the base of the Transylvanian ophiolites was reworked during Early Cretaceous east-facing orogeny. Only later on, that is, during Turonian-age orogeny, Biharia nappe and Transylvanian nappes were thrust together in an opposite direction (north-west) onto the Tisza Mega-Unit, that is, the Codru and Bihor nappe systems (see Schmid et al. 2008 for more details). Note that his concept, discussed in more detail later in the light of our new findings, also underlies the legend of Fig. 1.

\section{Cretaceous evolution}

Three distinct orogenic events characterize the Cretaceous evolution of the Apuseni Mountains. Post-tectonic cover sequences, sealing the structures formed by each of these events, offer the best time constraints. Some, but not all, of these events also affected the subsurface of the adjacent Transylvanian Basin and the internal Eastern Carpathians, considered as parts of the Dacia Mega-Unit by all authors. A large range of radiometric ages (Late Palaeozoic to Late Cretaceous; Soroiu et al. 1969; Pavelescu et al. 1975; Dallmeyer et al. 1999) is reported from the Apuseni Mountains. However, due to incomplete resetting of preAlpine ages and lack of microstructural control, of the published ages, these data occasionally do not allow for accurately constraining the individual deformational and metamorphic events affecting the basement rocks in Cretaceous times.

Early Cretaceous tectonism ('Austrian' phase in the Romanian literature) affected the Transylvanian nappes of the Apuseni Mountains, the Biharia nappe system, the subsurface of the Transylvanian Basin and the most internal East Carpathians (Săndulescu 1984; Schmid et al. 2008). In the case of the South Apuseni Mountains, thrusting (Bleahu et al. 1981; Balintoni and Iancu 1986) was partly contemporaneous with the deposition of syntectonic Barremian to Middle Albian flysch (the Feneş and Meteş Formations; Bleahu and Dimian 1967; Balc et al. 2007). This flysch transgressively covers the Transylvanian ophiolitic and island-arc series including their platform carbonate cover. Late Albian to Cenomanian post-tectonic cover sequences (e.g. Valea lui Paul Formation, basal parts of the Rameţi flysch; Bleahu and Dimian 1967; Ianovici et al. 1976; Balc et al. 2007) unconformably overlie the Early Cretaceous tectonic edifice of the South ApuseniTransylvanian nappes (Fig. 3), as well as the nappe edifice of the Eastern Carpathians (Săndulescu 1984). Some of the ${ }^{40} \mathrm{Ar} /{ }^{39} \mathrm{Ar}$ plateau ages from phyllonites in the Biharia basement (114-108 Ma, Dallmeyer et al. 1999) indicate that the Biharia nappe system was also affected by this Early Cretaceous tectonism. However, in the realm of the future Codru and Bihor nappe systems, sedimentation persisted until Turonian times (Săndulescu 1994); hence, Early Cretaceous orogeny and metamorphism cannot have affected these two nappe systems belonging to the Tisza Mega-Unit, at least not those parts of the basement that are adjacent to Turonian-age sediments. Because of this biostratigraphic constraint, we find it difficult to relate the ${ }^{40} \mathrm{Ar} /{ }^{39} \mathrm{Ar}$ muscovite plateau ages of around $100 \mathrm{Ma}$ reported from the eastern part of the Bihor unit (Dallmeyer et al. 1999) to the Early Cretaceous 'Austrian' phase or to some other Early Cretaceous regional thermal overprint in this part of the Apuseni Mountains. No detailed mesoscopic structural data on the kinematics of deformation are available yet for the Early Cretaceous event within the Biharia nappe system of the South Apuseni Mountains. However, on a regional scale, top-E thrusting (in presentday coordinates) is well known to govern the entire region attributed to the Dacia Mega-Unit, stretching from the South Apuseni Mountains over the Transylvanian Basin into the East Carpathians (Săndulescu 1994; Schmid et al. 2008). In summary, E-facing orogeny is clearly indicated on the basis of regional tectonic constraints for the entire Dacia Mega-Unit, but there are doubts for stratigraphic reasons that the Codru and Bihor nappe systems, being parts of the Tisza Mega-Unit, also underwent Early Cretaceous E-facing orogeny.

A second and separate Cretaceous tectonic event of Turonian age (known as the 'Intra-Turonian' phase) is well constrained by stratigraphic data. Locally, Lower Turonian sediments are involved in thrusting while elsewhere the uppermost Turonian strata forming the Gosau succession seal nappe contacts (Săndulescu 1984; Schuller 2004; Schuller and Frisch 2006; Schuller et al. 2009). This second tectonic event is $\mathrm{W}$-facing and led to the final geometry of the nappe stack as seen today, consisting of, from top to bottom, Bihor, Codru and Biharia nappe systems of the North Apuseni Mountains. Kinematic indicators, according to our own observations, indicate top-W to -NW thrusting in present-day coordinates. The continental to shallow-marine sediments at the base of the post-tectonic Gosau sediments (Figs. 2, 3) show onlap onto all three 
nappe systems. Turonian-age thrusting sealed by Gosau deposits is also widespread within the rest of the Tisza Mega-Unit and in the Eastern Alps (e.g. Haas and Pero 2004; Schuller et al. 2009). The Turonian-age nappe edifice (Săndulescu 1984) was substantially exhumed by erosion and massively shed detritus into the intramontane Gosautype sedimentary basins whose fill reaches thicknesses of up to $3 \mathrm{~km}$, locally $6.5 \mathrm{~km}$ (Balintoni 1994; Schuller 2004; Schuller and Frisch 2006). A Late Cretaceous (ConiacianCampanian) rapid cooling event related to erosion is also reported from the East Carpathians, that is, the Rodna horst located along the northern margin of the Transylvanian Basin (zircon fission-track ages; Gröger et al. 2008).

A last Cretaceous compressional deformation event occurred during the late Campanian to Maastrichtian ('Laramian' phase, Săndulescu 1984, 1994). This phase is characterized by dominant top-NW to -N and subordinate top-ESE high-angle thrusting, associated with strike-slip faulting. This latest Cretaceous deformation mainly affected the Biharia nappe system and the Transylvanian nappes (Bleahu et al. 1981; Balintoni 1994), and is also known from the subsurface of the adjacent Transylvanian Basin (Puini thrust, Fig. 2, later reactivated in Paleogene times; de Broucker et al. 1998; Merten et al. 2011). Deposition of the deep-marine turbidites, occasionally with coarse debris flows and olistoliths of the Upper Gosau Subgroup, including the Bozes flysch, started in Campanian to Maastrichtian time and was associated with substantial subsidence (Schuller 2004; Schuller et al. 2009). According to these authors, deposition of the Upper Gosau Subgroup was syn-tectonic with 'Laramian' shortening and ceased before Cenozoic times.

The Apuseni Mountains were also affected by intrusion and extrusion of Upper Cretaceous calc-alkaline suites (e.g. Bleahu et al. 1981, 1984; Berza et al. 1998). These magmatites (named 'banatites' after von Cotta 1864) are part of a Late Cretaceous magmatic belt (Apuseni-Banat-TimokSredna Gora belt), which can be followed from the Apuseni through the South Carpathians and the Balkans to the Black Sea coast (e.g. von Cotta 1864; Berza et al. 1998; Heinrich and Neubauer 2002; von Quadt et al. 2005; Zimmerman et al. 2008). However, this magmatic activity is unrelated to orogeny within the Apuseni Mountains and started to evolve in a back-arc setting in respect to the N- to NEward subduction of Neotethys oceanic crust below the European margin in the Hellenides and Dinarides some $93 \mathrm{Ma}$ ago in the case of the Balkan Mountains (i.e. Berza et al. 1998; Heinrich and Neubauer 2002; von Quadt et al. 2005; Schmid et al. 2008; Zimmerman et al. 2008). Recent Re-Os molybdenite ages dating this mineralization give minimum age for the magmatism to 83-72 Ma for the case of the Apuseni Mountains and the nearby Timok area (Zimmerman et al. 2008).
Cenozoic evolution

Palaeocene to Early Priabonian continental and lacustrine sediments of the Jibou Formation are the oldest members of the Cenozoic sequences that unconformably overlie the Apuseni Mountains at the border to the NW part of the Transylvanian Basin (Schuller 2004; Merten et al. 2011). They are at the base of the first out of four pre-mid-Miocene sedimentary cycles recorded in the Transylvanian Basin, each one with shallow-marine grading into deepmarine deposits (Proust and Hosu 1996; Filipescu 2001; Krézsek and Bally 2006; Merten et al. 2011). The first cycle is interpreted as the result of post-'Laramian' erosion of the Apuseni nappe stack (Krézsek and Bally 2006). Merten et al. (2011) documented renewed compression during early to mid-Eocene and during Oligocene times in the north-eastern Apuseni Mountains (Mezes thrust, Fig. 2; see also Györfi et al. 1999). In the Transylvanian Basin, immediately east of the Apuseni Mountains, another Paleogene-age thrust reactivated the Puini thrust that first formed during the latest Cretaceous (Fig. 2; de Broucker et al. 1998). A last compressional event is related to thrusting north of the Transylvanian Basin during the Early Miocene (Tischler et al. 2007).

Rapid subsidence of the Transylvanian Basin started in earliest mid-Miocene times, that is, at around $16 \mathrm{Ma}$, in the back-arc area of the eastward retreating Carpathian arc (e.g. Horvath et al. 2006; Cloetingh et al. 2006). This was also the time of ongoing clockwise rotation of the Tisza and Dacia Mega-Units around a vertical axis by up to $70^{\circ}$ (e.g. Patrascu et al. 1990; Patrascu 1993; Panaiotu 1998, 1999). This rotation started earlier, that is, in the Oligocene or still earlier (Roşu et al. 2004; Marton et al. 2007; Fügenschuh and Schmid 2005) and was related to the invasion of the Tisza and Dacia Mega-Units into the Carpathian embayment. Supposedly, the Apuseni Mountains remained a highland during most of the Cenozoic. The Neogene evolution of the area was accompanied by widespread calcalkaline and alkaline magmatism, which reached its climax between 15 and $7 \mathrm{Ma}$ and finally ceased at around $2 \mathrm{Ma}$ (e.g. Pécskay et al. 1995; Roşu et al. 1997, 2000, 2004).

\section{Fission-track analysis}

Analytical method

Whole rock samples were crushed; subsequently, apatite and zircon grains were recovered by conventional heavy liquid and magnetic methods. Apatite grains were mounted in epoxy resin, polished and etched with $5.5 \mathrm{~N} \mathrm{HNO}_{3}$ at $21{ }^{\circ} \mathrm{C}$ for $20 \mathrm{~s}$. Zircon grains were etched in an eutectic mixture of $\mathrm{KOH}$ and $\mathrm{NaOH}$ at $220{ }^{\circ} \mathrm{C}$ for between 10 and 
$24 \mathrm{~h}$. Irradiation was carried out at the OSU facility, Oregon State University Radiation Center, USA. Microscopic analysis was completed at Basel University using an optical microscope with a Kinetek computer-driven stage (Dumitru 1995). All ages were determined using the $\zeta$ approach (Hurford and Green 1983) with a $\zeta$ value of $332 \pm 7$ for apatite (CN5 standard glass) and $122 \pm 2$ for zircon (CN1 standard glass) (Table 1, analyst: A. Kounov). They are reported as central ages (Galbraith and Laslett 1993 ) with a $1 \sigma$ error (Table 1 ). The magnification used was $\times 1,250$ for apatite and $\times 1,600$ (dry objective) for zircon. Horizontal confined track lengths in apatite grains were measured at a magnification of $\times 1,250$. Fission-track etch-pit diameters (Dpar) were measured at a magnification of $\times 2,500$ in order to estimate the compositional influence on fission-track annealing (Carlson et al. 1999).

The sediment samples that had failed the Chi-square test $(P \chi<5 \%)$ were considered as containing minerals that had experienced different thermal histories and therefore belong to different detrital populations (e.g. Brandon et al. 1998; Garver et al. 2000; Stewart and Brandon 2004). For statistical separation of the different detrital populations, the binominal 'peak-fitting' method (Galbraith and Green 1990; Galbraith and Laslett 1993) was applied by using the BinomFit $^{\circledR}$ software (Brandon 1992).

The temperatures at which fission tracks in apatite and zircon minerals partially anneal (i.e. partial isotopic resetting) are not sharply defined. The temperature range within which partial track annealing occurs is known as the partial annealing zone (PAZ). The effective closure of the system lies within this PAZ and depends on overall cooling rate and kinetic properties of the minerals. The specific partial annealing zone for apatite lies between 60 and $120{ }^{\circ} \mathrm{C}$ (Green and Duddy 1989; Corrigan 1993), with a mean effective closure temperature of $110 \pm 10{ }^{\circ} \mathrm{C}$ (Gleadow and Duddy 1981).

Unfortunately, our knowledge of zircon annealing is less advanced and a wide range of temperature bounds has been published for the partial annealing zone of zircon. Yamada et al. (1995) suggest temperature limits of $\sim 390$ to $170{ }^{\circ} \mathrm{C}$, whereas Tagami and Dumitru (1996) and Tagami et al. (1998) suggested temperature limits of $\sim 310$ to $230{ }^{\circ} \mathrm{C}$. Recently, in his overview on the zircon fissiontrack dating method, Tagami (2005) reported temperature ranges for the closure temperature between $\sim 300$ and $200{ }^{\circ} \mathrm{C}$. Accordingly, we use a value of $250 \pm 50{ }^{\circ} \mathrm{C}$ for the mean effective closure temperature and the $200-300{ }^{\circ} \mathrm{C}$ temperature interval for the partial annealing zone.

Fission-track results

Zircon and apatite fission-track analyses were performed on samples from different tectonic units in the East
Apuseni Mountains. Geographical and geological locations and analytical results are shown in Fig. 3 and Table 1.

\section{Zircon fission-track data}

The samples taken from pre-Early Cretaceous rocks in the area yielded zircon FT ages between $120 \pm 7$ and $71 \pm 4$ Ma. Since these ages are younger than the protoliths (Fig. 3; Table 1), all dated samples are inferred to have been at temperatures higher than $\sim 250{ }^{\circ} \mathrm{C}$ before or during Late Cretaceous times. Interestingly, the six samples taken from the easternmost tectonic units, occupying the structurally highest tectonic positions in the present-day nappe stack, show the oldest ages, namely late Early Cretaceous ages (Aptian and Albian, 120-103 Ma, Table 1; Figs. 3, 4a). Within this older group, three samples are from the Jurassic volcanics of the Transylvanides and their Jurassic to Lower Cretaceous sedimentary cover (AP15, AP16 and AP21), another three (AP22, AP23 and AP24) are from the immediately underlying Vidolm nappe (Săndulescu 1984).

The ten ages obtained from the basement of the Bihor, Codru, Biharia and Baja de Arieş nappes are systematically and significantly younger; they range between 95 and $71 \mathrm{Ma}$ (Cenomanian to Campanian; Table 1; Figs. 3, 4a).

The three samples taken from the Cretaceous cover yield zircon FT central ages between $148 \pm 7$ and $122 \pm 6 \mathrm{Ma}$ (Table 1; Fig. 3). All three samples failed the $\mathrm{P} \chi^{2}$ test. Hence, we considered the obtained central ages as unrelated to the cooling of the sedimentary samples; they rather reflect a mixture of different detrital populations (Table 1).

Zircon single-grain ages from the Barremian to Aptian (130-112 Ma) Feneş Formation (sample AP35, Fig. 5c) are between $78 \pm 15$ and $297 \pm 98 \mathrm{Ma}$. Two detrital populations at $187 \pm 31$ and $121 \pm 17$ Ma can be statistically separated. Within error, the younger population overlaps with the depositional age. Given the wildflysch character of this formation, the younger detrital population possibly indicates rapid exhumation of parts of the source area, penecontemporaneous with deposition. However, post-depositional partial resetting cannot be ruled out since the youngest single-grain ages (at around $80 \mathrm{Ma}$ ) post-date deposition (Fig. 5c). Moreover, this sample shows a clear correlation between single-grain age and uranium content (Fig. 6), which indicates possible partial resetting. Thereby, the grains with higher uranium content that accumulated more alpha damages experienced more annealing and consequently exhibit relatively younger ages.

Two detrital populations, $141 \pm 20$ and $97 \pm 19 \mathrm{Ma}$, were statistically separated from the Cenomanian to Maastrichtian (100-65 Ma) Rameti Formation (sample AP46, Fig. 5b; Balc et al. 2007). The age of the younger 


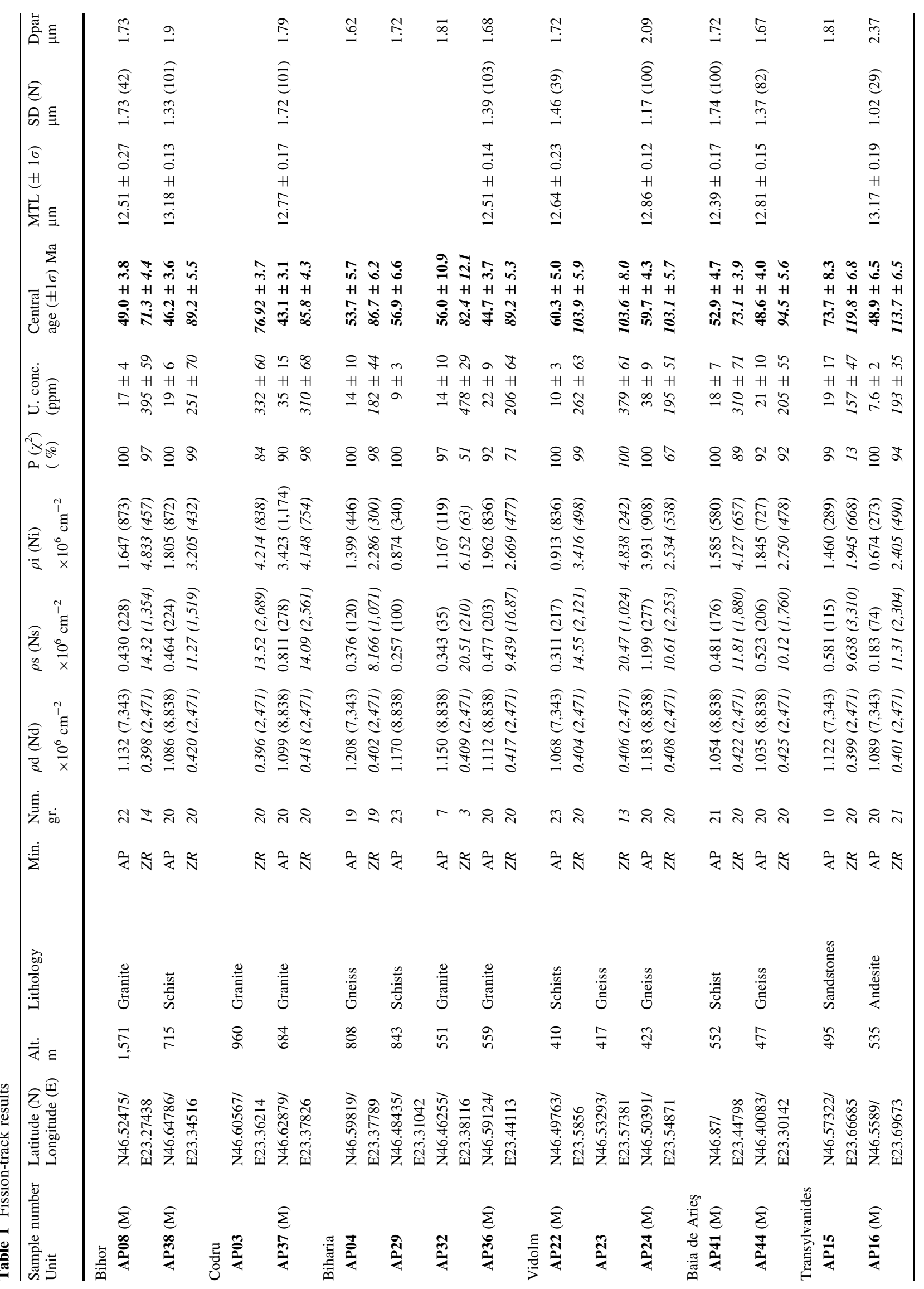




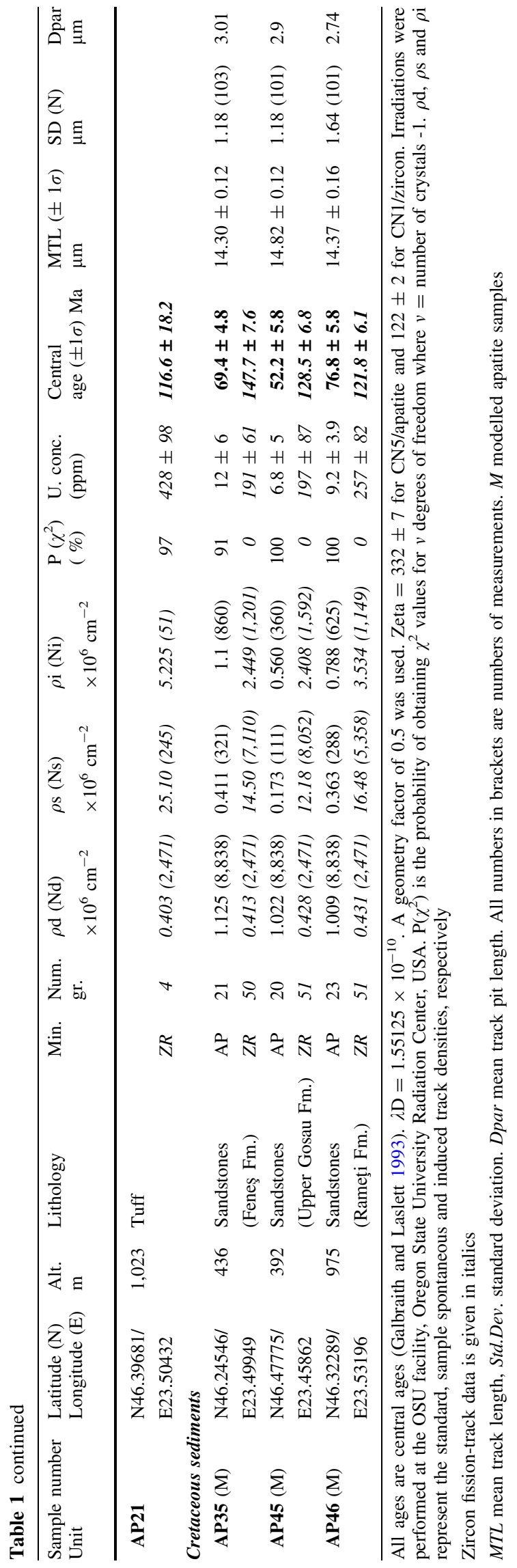

population considerably overlaps with the depositional age (Fig. 5b); this suggests fast exhumation of a part of the source area penecontemporaneous with deposition.

Sample AP45 from the turbiditic Upper Campanian to Maastrichtian (75-65 Ma) Upper Gosau Subgroup also shows two detrital populations: one at $156 \pm 17$ and the other at $96 \pm 14 \mathrm{Ma}$ (Fig. 5a). In this case, however, the younger detrital population is about $20 \mathrm{Ma}$ older than the age of deposition (Fig. 5a).

\section{Apatite fission-track data}

The thirteen apatite FT ages from pre-Lower Cretaceous formations are all between 74 and $43 \mathrm{Ma}$. This suggests that the basement of the Bihor, Codru and Biharia nappe systems, as well as the island-arc volcanics and their Jurassic cover, has been at temperatures higher than $\sim 110{ }^{\circ} \mathrm{C}$ before cooling in latest Cretaceous to Paleogene times (Figs. 3, 4b). The mean track lengths are between 12.5 and $13.2 \mu \mathrm{m}$ with a standard deviation of 1.74-1.02 $\mu \mathrm{m}$ (Table 1). The mean track lengths of samples with less than 30 measured lengths are not listed in Table 1 and have not been used for thermal modelling since they do not allow for robust modelling.

The sample from the Upper Gosau Subgroup (AP45) shows an apatite FT age of $52 \pm 6 \mathrm{Ma}$, younger than its age of deposition, with a relatively long mean track length of $14.8 \pm 0.1 \mu \mathrm{m}$ (Table 1). The two sandstone samples from the south-eastern part of the studied area (Fig. 3) have older apatite ages. Sample AP46 (Rameţi Formation) yielded $77 \pm 6 \mathrm{Ma}$, that is, an age that still overlaps with the age of deposition. Sample AP35 (Feneş Formation) gave $69 \pm 5 \mathrm{Ma}$, an age that clearly post-dates deposition and falls into the age interval obtained from the pre-Lower Cretaceous formations. The measured mean track lengths for the last two samples are $14.4 \pm 0.2$ and $14.3 \pm 0.1 \mu \mathrm{m}$, respectively (Table 1 ).

\section{Apatite fission-track thermal modelling}

Fission tracks in apatite continuously form through time, with an approximately uniform initial mean length of $\sim 16.3 \mu \mathrm{m}$ (Gleadow et al. 1986). Upon heating, tracks gradually anneal and shorten to a length that depends on the time interval the grains remained at high temperatures and the maximum temperature to which the apatites were exposed. For example, tracks become completely annealed at a temperature of $110-120^{\circ} \mathrm{C}$ for a period of $10^{5}$ $10^{6}$ years (Gleadow and Duddy 1981). Annealing characteristics allow for the generation of time-temperature paths by inverse modelling (e.g. Gallagher and Sambridge 1994; Ketcham et al. 2000). As the resolution of the AFT thermochronometer is limited to the temperature range 

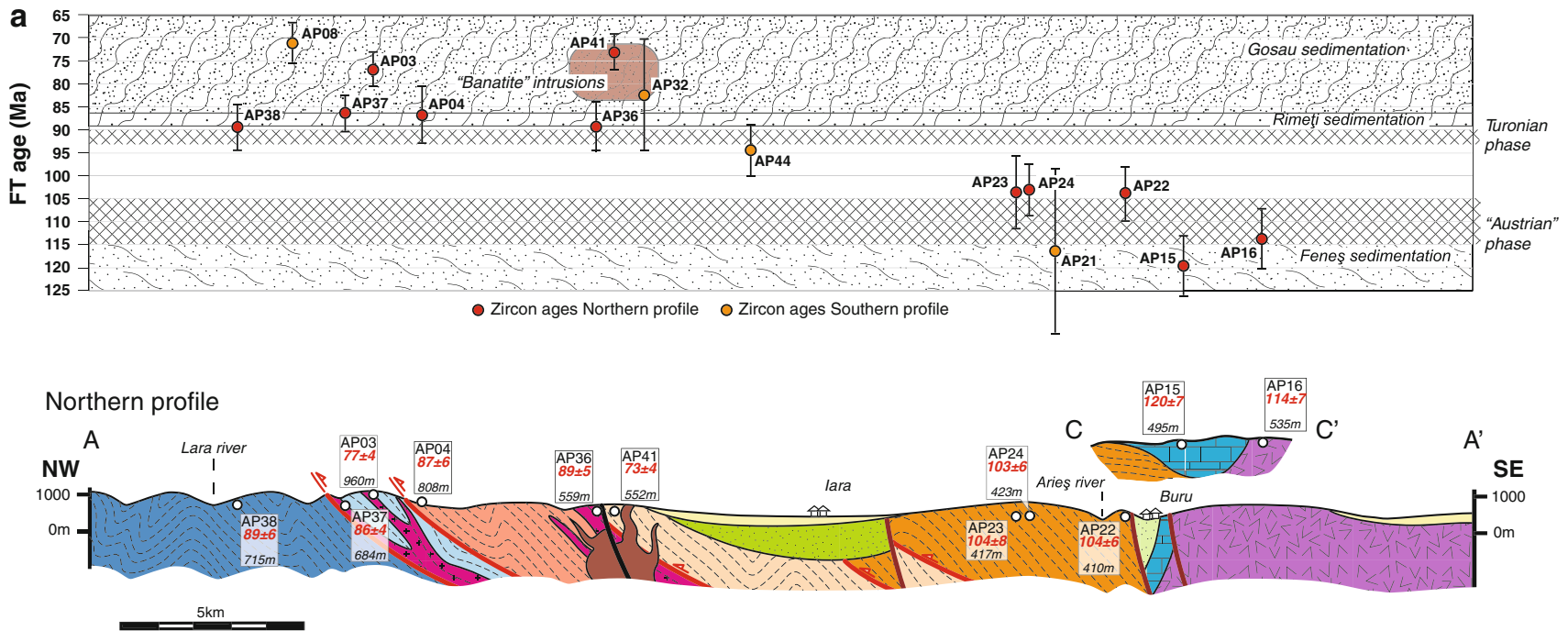

Southern profile
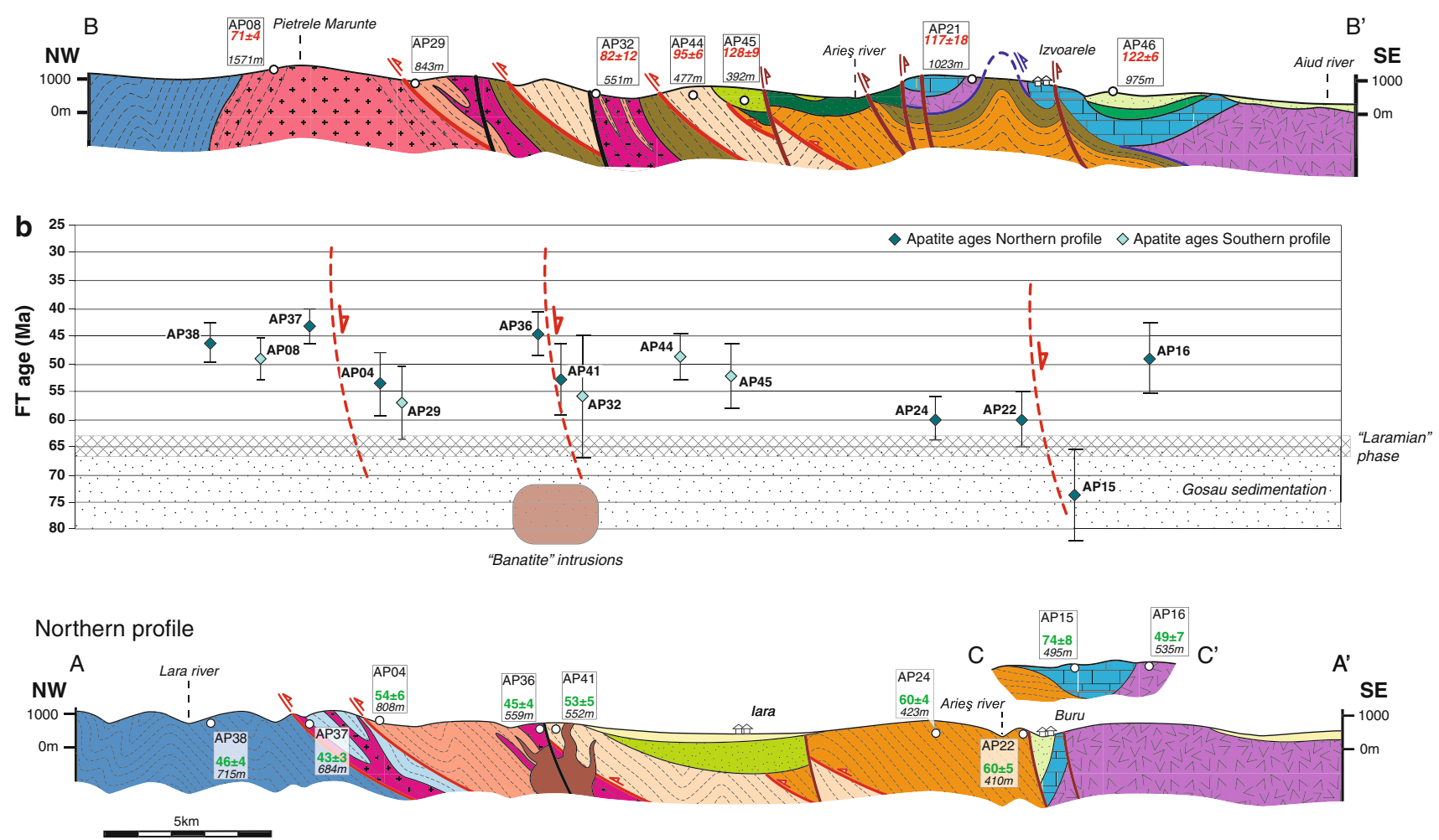

Southern profile

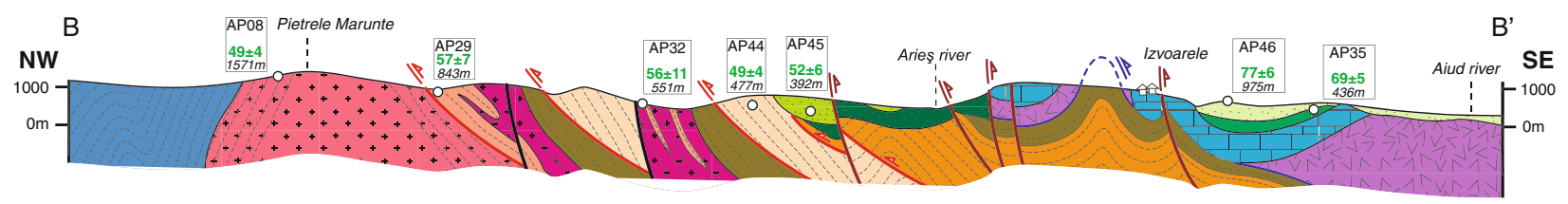

Fig. 4 Sections $A A^{\prime} B B^{\prime}$ and $C C^{\prime}$ (Fig. 3) with a zircon and $\mathbf{b}$ apatite FT central ages. Lithological key as in Fig. 3 

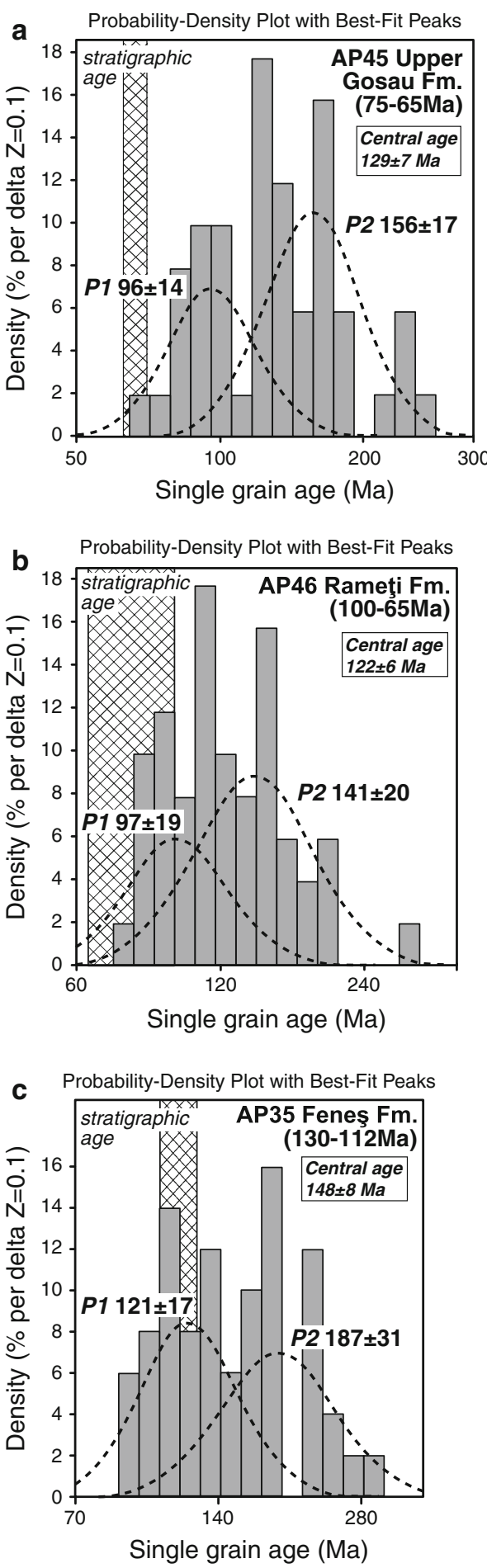

Fig. 5 Frequency distribution of the zircon single-grain ages from Cretaceous sandstone samples with statistically separated detrital populations, using the BinomFit software (Brandon 1992). a Upper Campanian to Maastrichtian (75-65 Ma) Upper Gosau Subgroup, sample AP45. b Cenomanian to Maastrichtian (100-65 Ma) Rameţi Formation, sample AP46. c Barremian to Aptian (130-112 Ma) Feneş Formation, sample AP35

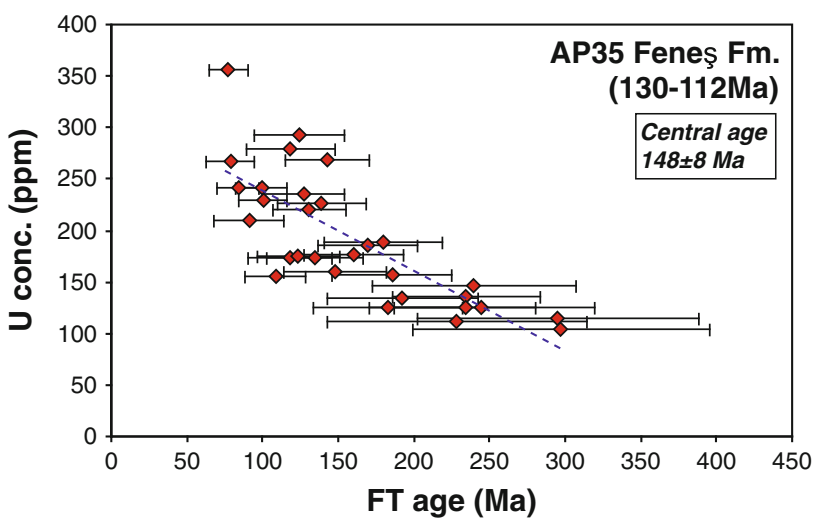

Fig. 6 Zircon FT single-grain ages from the Barremian to Aptian (130-112 Ma) Feneş Formation sample AP35 versus U content

$120-60{ }^{\circ} \mathrm{C}$ (Laslett et al. 1987), the modelled paths of the $t-T$ envelope outside this temperature range are not necessarily representative for the thermal evolution of a sample.

Apatite age and track-length distributions were modelled with the program HeFTy (Ketcham et al. 2000). Fission-track age, track-length distribution and etch-pit diameters (Dpar), in combination with user-defined timetemperature $(t-T)$ boxes, as well as zircon fission-track ages for some of the models, served as input parameters. An inverse Monte Carlo algorithm with a multi-kinetic annealing model (Ketcham et al. 2007) was used to generate time-temperature paths. The algorithm generates a large number of time-temperature paths, which are tested with respect to the input data. Thereby, the $t-T$ paths are forced to pass through user-defined time-temperature boxes. The fits between measured and modelled data are statistically evaluated and characterized by the 'goodness of fit' value (GOF). A 'good' result corresponds to values $>0.5$, whereas a value of 0.05 or higher is considered to reflect an 'acceptable' fit between modelled and measured data. Note that the 'best' thermal history obtained during this process is not necessarily the only possible one. Other thermal histories may match the observed data similarly well, and it is therefore imperative to also consider as many geological constraints as possible for determining the most likely path.

Amongst the samples taken from the pre-Cretaceous basement, a total of nine samples could be modelled successfully. Two groups of samples whose latest Cretaceous to Cenozoic cooling histories differ were defined and shown in Figs. 7 and 8, respectively. All modelling results are presented by 50 'good' individual paths (purple lines) $(\mathrm{GOF}>0.5)$ and by the 'best' thermal history obtained for each sample (black dashed lines in Figs. 7, 8, 9).

A first group of modelled samples (Group 1) includes one sample from the Bihor unit collected at high altitude 
Fig. 7 Modelled thermal histories and comparison between predicted and observed fission-track parameters for four samples from the Baia de Arieş and Bihor nappes (Group 1 of Fig. 10) that reveal an earlier onset of cooling through the apatite partial annealing zone (PAZ) (75-60 Ma, dark blue vertical band), followed by ongoing but slower cooling across the low-temperature part of the apatite FT PAZ

(60-40 Ma age interval, pale blue vertical bands). Dark blue lines delimit user-defined time (t)-temperature (T) boxes. Thick green-dashed horizontal lines within individual models at 60-120 ${ }^{\circ} \mathrm{C}$ bracket the partial annealing zone $(P A Z)$ for apatite within the temperature limits as given by Laslett et al. (1987).

Thick dashed black lines represent the best fit paths while the purple lines represent 50 'good' thermal history paths corresponding to the goodnessof-fit value $>0.5$ (for details see the text). The red squares represent the measured zircon fission-track central ages of the modelled samples including their $1 \sigma$ errors. MTL mean track length; $N$ number of horizontal confined tracks measured

\section{Bihor}
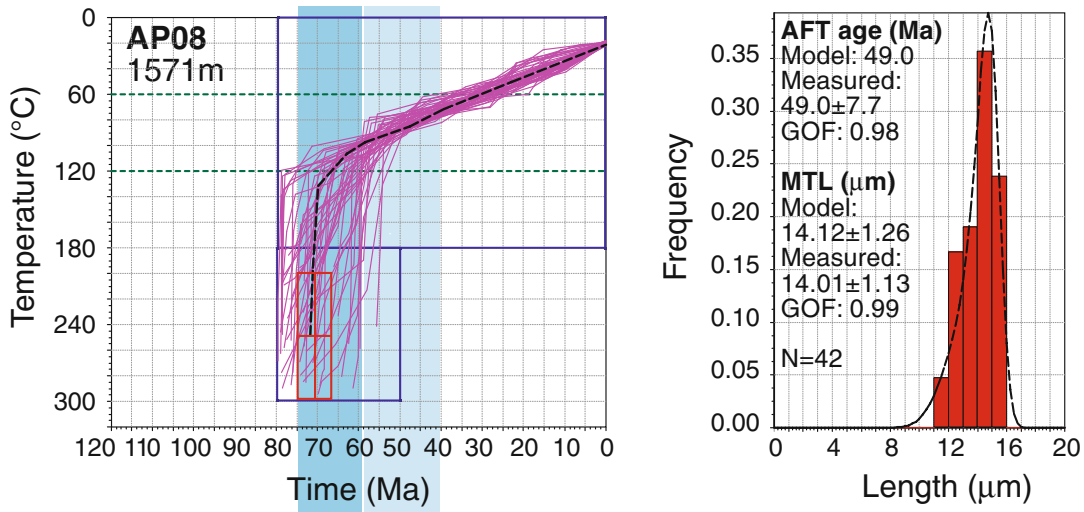

Baia de Arieş
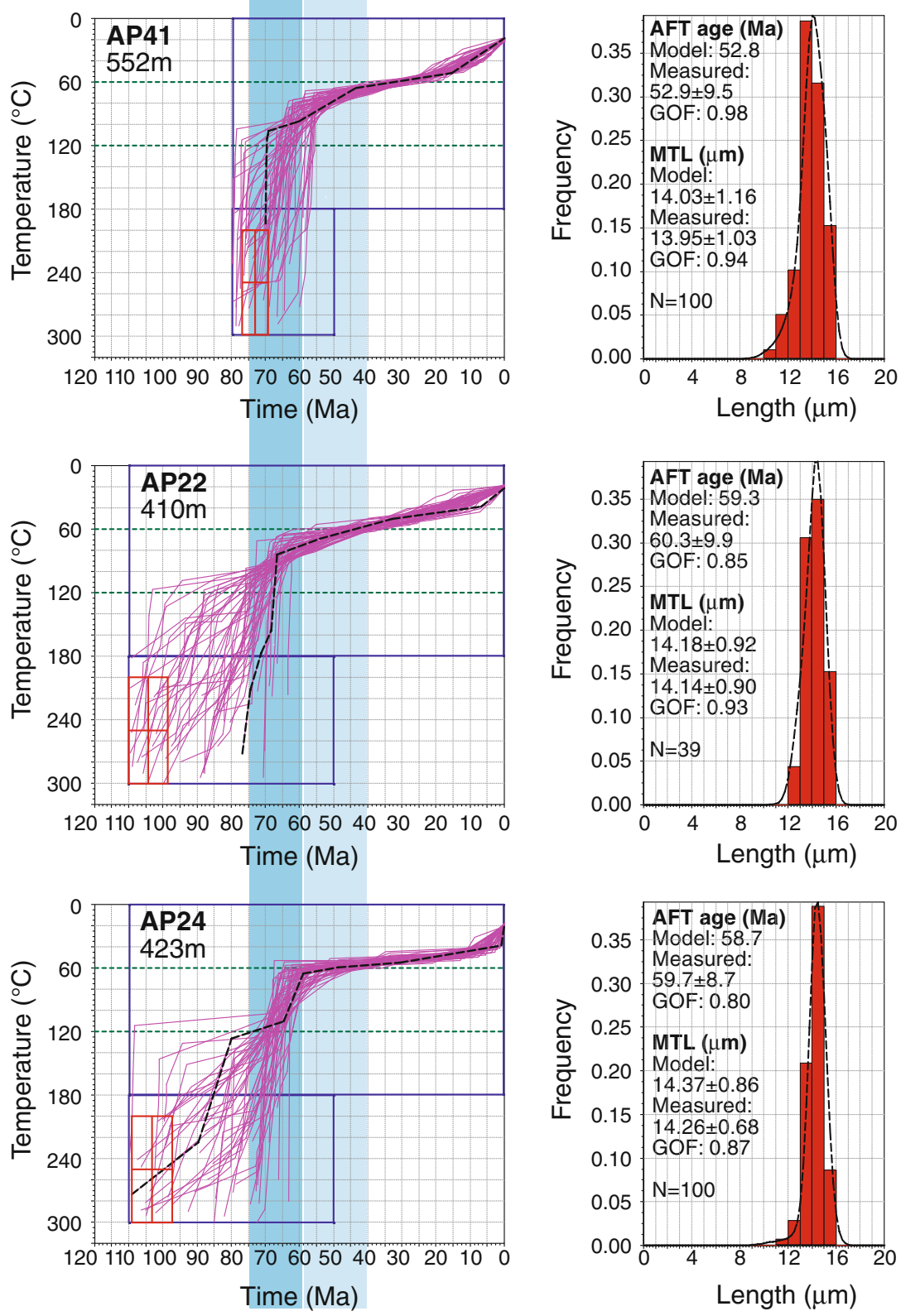

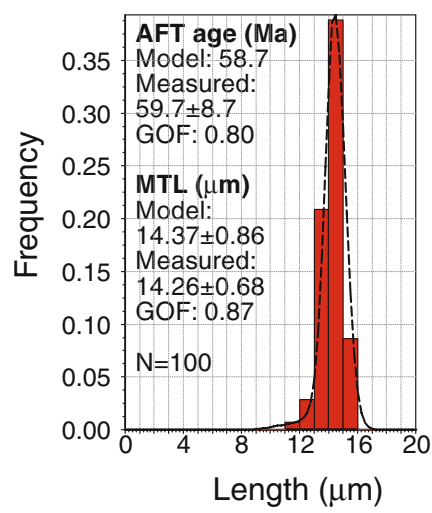



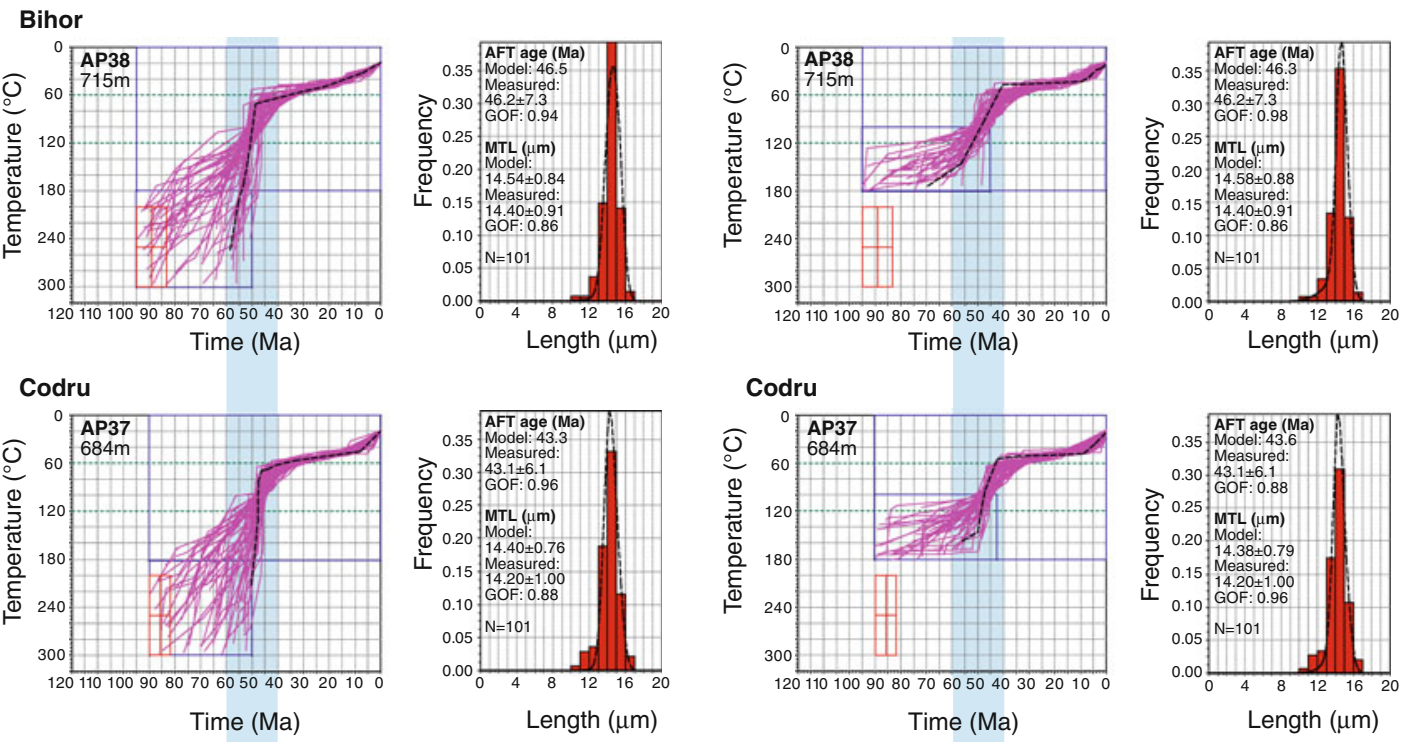

\section{Codru}
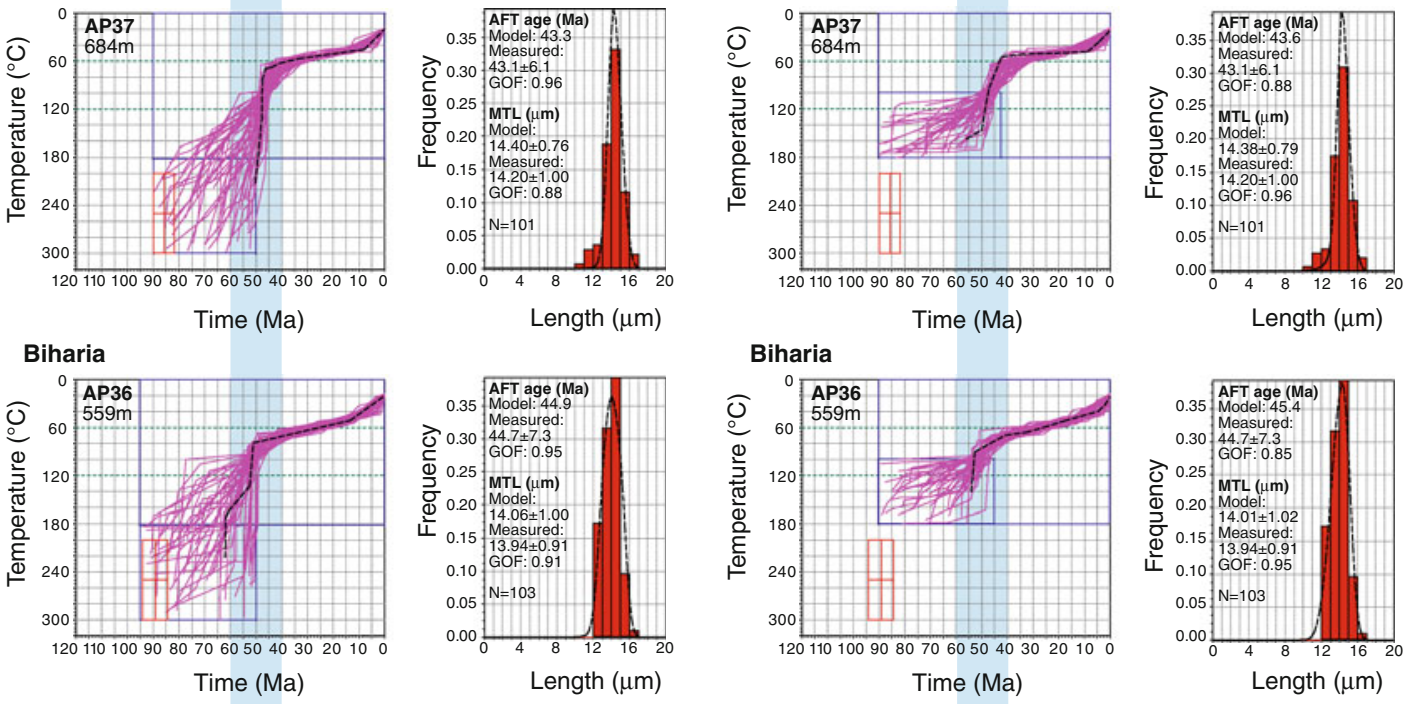

Baia de Aries
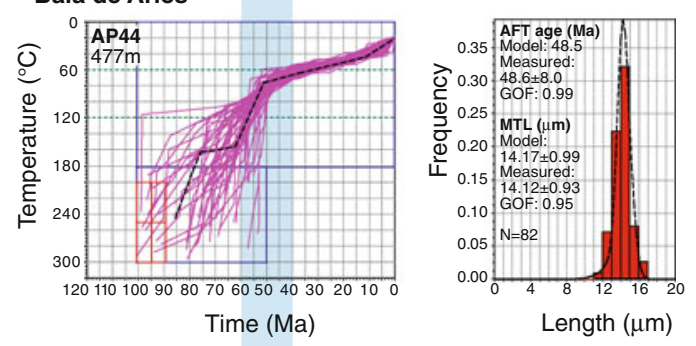

Baia de Aries
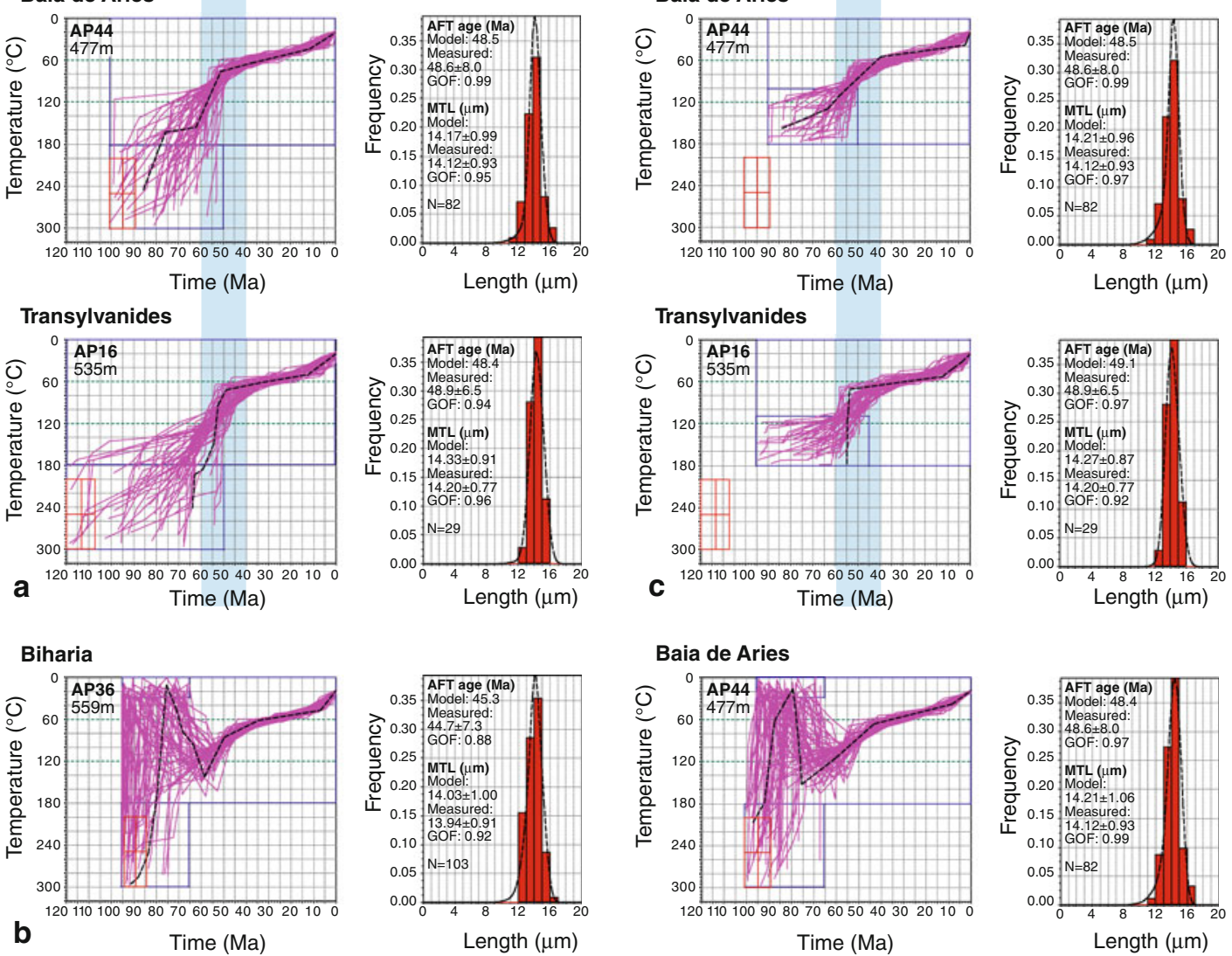
4 Fig. 8 Modelled thermal histories and comparison between predicted and observed fission-track parameters for a set of five samples from the studied area (Group 2 of Fig. 10) that reveal cooling through the apatite FT PAZ within the 60-40 Ma age interval (pale blue vertical bands, see Figs. 3 and 4 for sample locations). For further details, see legend of Fig. 7. a Modelling step 1, interrogating all possibilities regarding cooling from known zircon closure temperatures to presentday surface temperature (see text). b Modelling step 2, performed on the two samples amongst this group that lay near the surface of the earth during the age span of deposition of the Gosau sediments (see text). c Modelling step 3, checking for robustness of steps 1 and 2 by constraining the $180^{\circ}-0{ }^{\circ} \mathrm{C}$ temperature interval to the $95-0$ Ma time interval (95 Ma: earliest possible time of exposure at the surface, see text)

(1,571 m, AP08), one from the Baia de Arieş nappe (AP41) and two from the Vidolm nappe (AP22 and AP24) that are immediately overlain by the Transylvanian nappe (Figs. 3, 7). For the modelling of Group 1 samples, two
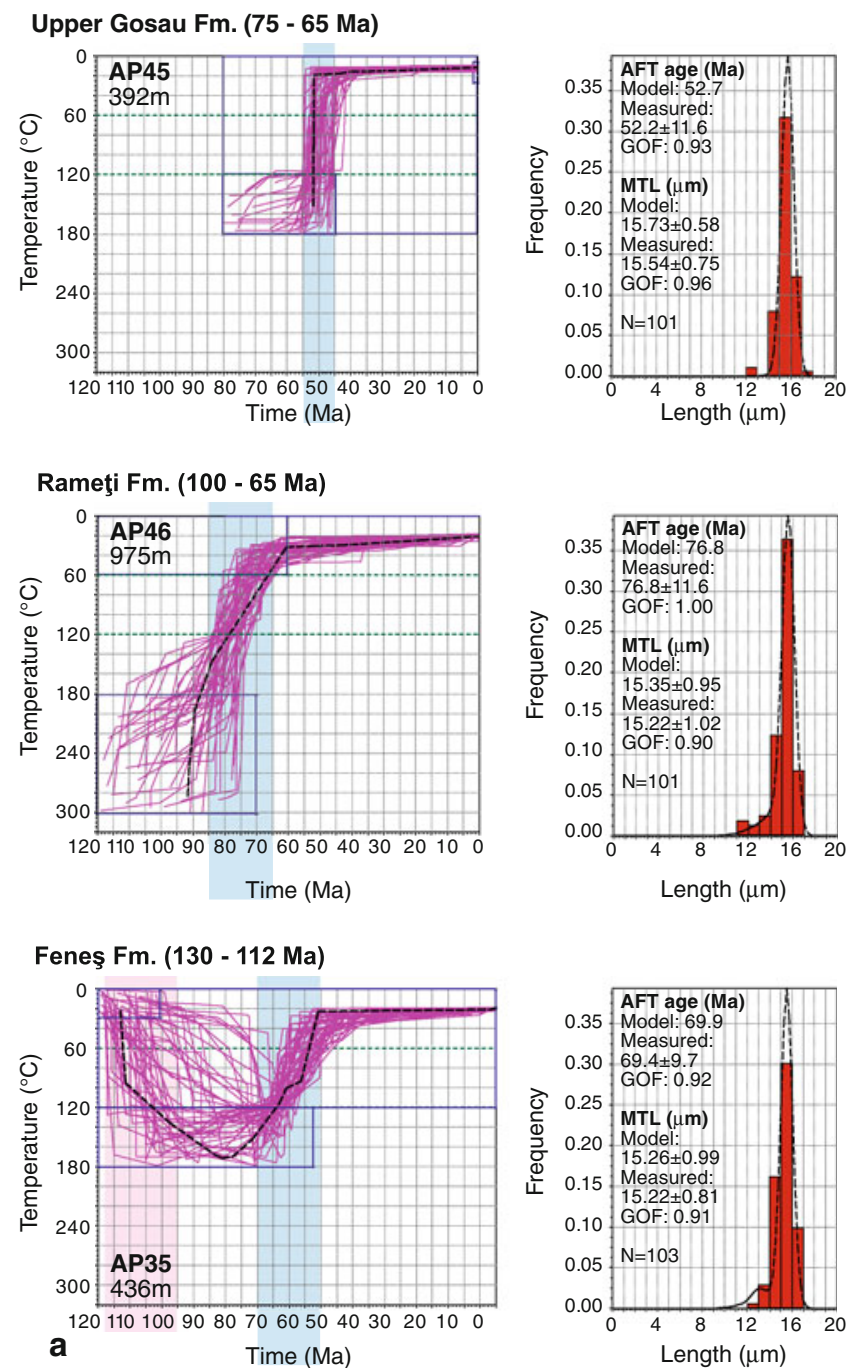

Fig. 9 Modelled thermal histories and comparison between the predicted fission-track parameters and the observed data for the samples from Cretaceous sedimentary units. The light blue vertical bands mark the time intervals for cooling through the apatite time-temperature boxes were defined, one between 300 and $180{ }^{\circ} \mathrm{C}$ and the other between $180^{\circ}$ and $0{ }^{\circ} \mathrm{C}$; both cover the time between the cooling through the zircon mean effective closure temperature and the present day. The Group 1 samples (Fig. 7) started to enter the high temperature part of the apatite partial annealing zone around $75 \mathrm{Ma}$ ago, that is, in Campanian times when deposition of the Gosau beds was still going on. Between 60 and $40 \mathrm{Ma}$, still within the partial annealing zone, the cooling rate markedly slowed down to very low cooling rates. Note that the Group 1 samples are either from high altitude (AP08) or from the structurally higher parts of the Biharia nappe system.

A second group (Group 2) includes one sample each from the Bihor (AP38) and Codru (AP37) nappe systems, respectively, as well as one each from the Biharia (AP36),
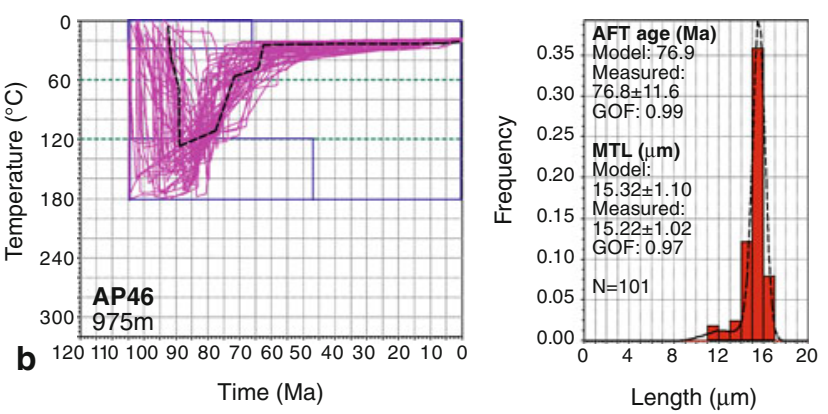

annealing window, the pale pink vertical band marks the modelled heating event for sample AP35 (120-100 Ma) revealed by the model. For further details, see legend of Fig. 7 
the Baia de Arieş (AP44) and the Transylvanides (AP16) nappes. The Group 2 samples (Fig. 8) did not enter the high temperature part of the apatite partial annealing zone before about $60 \mathrm{Ma}$ ago, that is, after deposition of the Gosau beds. The modelling of the Group 2 samples was performed in three steps, each modelling step being constrained by different combinations of time-temperature boxes. In a first step, two time-temperature boxes were defined, again one between 300 and $180{ }^{\circ} \mathrm{C}$ and the other between $180^{\circ}$ and $0{ }^{\circ} \mathrm{C}$, covering the time between the cooling through the zircon mean effective closure temperature and the present day (Fig. 8a). This first step takes into account the poor constraints on the post-Early Cretaceous geological evolution of this group of rocks. Additionally, it interrogates a great variety of possibilities regarding the cooling history of these five samples (Fig. 8a). Group 2 samples exhibit modest (compared to other tectonic settings) cooling rates through the apatite partial annealing zone between 60 and $40 \mathrm{Ma}$. This cooling interval is constrained by 50 'good' individual paths of each sample (GOF $>0.5$, Fig. 8a). In a second step, two samples (AP36 and AP44), both collected near the transgressive contact of the Gosau-type Upper Cretaceous sediments, allowed for adding a third time-temperature box forcing the individual time-temperature paths to pass through the temperature interval $0-30{ }^{\circ} \mathrm{C}$ between 95 and $65 \mathrm{Ma}$ (age of deposition of the Gosau beds) when samples AP 36 and AP 44 (Fig. 8b) must have been exposed at or near the earth's surface. Modelling of these two samples indicates that reheating to temperatures of around or slightly above $120{ }^{\circ} \mathrm{C}$ occurred before they started to cool again from about $55 \mathrm{Ma}$ onward. This still matches with the modelling performed for this group of samples without the additional constraint (Fig. 8a). Hence, by combining the information from these two modelling steps (Fig. 8a, b), we conclude that all of them must have been at temperatures higher than some $110{ }^{\circ} \mathrm{C}$ before $60 \mathrm{Ma}$ ago, even though the samples of Group 2 started to cool since some 120-80 Ma ago (their range of zircon FT ages including error) to temperatures below $\sim 250{ }^{\circ} \mathrm{C}$. This inference was used for performing a third step of modelling during which the possible time-temperature paths were constrained to be contained within the $180^{\circ}-0{ }^{\circ} \mathrm{C}$ temperature interval between $95 \mathrm{Ma}$ ago (earliest possible onset of deposition of the Gosau sediments) and the present (Fig. 8c). This third step was undertaken in order to better constrain the modelling of cooling within the apatite partial annealing zone where the most reliable time-temperature paths are obtained. This third step yields very similar results. This demonstrates that the results of the modelling are very robust and allows for excluding other substantially different solutions. In conclusion, the three-step modelling shows that all Group 2 samples experienced modest cooling rates through the $120-60{ }^{\circ} \mathrm{C}$ temperature interval between 60 and $40 \mathrm{Ma}$. Note that not all samples necessarily cooled to near surface temperatures before experiencing a second heating event at temperatures $\sim 120{ }^{\circ} \mathrm{C}$ between 80 and $60 \mathrm{Ma}$, as suggested by the modelling procedure leading to Fig. 8b. Possibly, some of the samples, namely those from far below the transgression of the Gosau-type sediments, have never been exhumed to near the surface before the onset of the Gosau sedimentation. Some possibly escaped the 80-60 Ma heating event and rather experienced ongoing cooling from temperatures $\sim 250^{\circ}$ since the time indicated by their zircon FT ages (Fig. 8a).

The modelling results of three samples taken from Cretaceous sediments (Fig. 3) are shown in Fig. 9. The sample from the Upper Gosau Subgroup (AP45) cools fast through the apatite FT annealing zone between 55 and $45 \mathrm{Ma}$ ago (Fig. 9). Modelling shows that the sample must have been reheated after deposition to temperatures higher than the FT closure temperature for apatite, that is, certainly after $75 \mathrm{Ma}$. A post-depositional thermal event reaching temperatures higher than $120{ }^{\circ} \mathrm{C}$ is also indicated by the modelling of sample AP35 from the Feneş Formation, but this time earlier, that is, between 120 and $100 \mathrm{Ma}$ (Fig. 9). The model indicates subsequent cooling to temperatures below $60{ }^{\circ} \mathrm{C}$ between 75 and $55 \mathrm{Ma}$. Modelling of the sample from the Late Cretaceous Rameţi Formation (AP46) shows relatively fast cooling below some $120^{\circ}$ already between 85 and $65 \mathrm{Ma}$ ago (Fig. 9a). This could be considered as cooling of the source rocks penecontemporaneous with deposition because the apatite FT central age ( $77 \pm 6 \mathrm{Ma}$, Table 1$)$ and the inferred cooling interval overlap with the interval of deposition (Coniacian to early Campanian, 89-77 Ma; Balc et al. 2007). To test the possibility that post-depositional heating may have also occurred in the case of this formation, we also performed modelling by adding a time-temperature box with a $0-30{ }^{\circ} \mathrm{C}$ temperature interval for the maximum possible 105-65 Ma age range of deposition. This modelling suggests that the samples were heated to temperatures higher than $120{ }^{\circ} \mathrm{C}$ very quickly between some 105 and $85 \mathrm{Ma}$, that is, immediately after their deposition (Fig. 9b). If correct, this interpretation indicates an early age of deposition of sample AP46 (pre-85 Ma). In view of the wildflysch character of the Rameţi Formation, deposition could have been quickly followed by a heating event due to ongoing burial by syn-depositional thrusting. Since an exact biostratigraphical determination of the age of the sampled sedimentary sequence in the Rameţi Formation is not available, the results of this modelling are not conclusive. It is not entirely clear whether the suggested cooling followed post-depositional heating, or whether it just reflects cooling in the exhumed and eroded source area immediately before erosion and deposition. 


\section{Discussion of the tectonic evolution of the Apuseni Mountains}

Based on reconnaissance fieldwork and available literature data on the structural evolution of the area, we now discuss possible tectonic scenarios that are in line with the thermal history of the area as reconstructed from the new fissiontrack data (Fig. 10). Thereby, we also make use of previously published geochronological data. In the following, the discussion proceeds in geochronological order.

Late Jurassic tectonic contact between Vidolm nappe and Transylvanian ophiolites

Dallmeyer et al. (1999) reported a $155.5 \pm 0.4$ Ma hornblende ${ }^{40} \mathrm{Ar} /{ }^{39} \mathrm{Ar}$ plateau age obtained from amphibolites (their sample 18) of the Vidolm nappe near the locality Buru (Fig. 3), that is, in close vicinity to the Transylvanian nappe and near our samples AP22, AP23 and AP24. Since amphibole is known to be a reliable monitor of polyphase metamorphic evolution (e.g. Villa et al. 2000), it is very likely that this sample indicates a Jurassic thermal event. Interestingly, all other multigrain hornblende concentrates from pre-Triassic rocks analysed by Dallmeyer et al. (1999) either yielded pre-Triassic plateau ages (Bihor and Codru nappe systems) or considerably younger, that is, Early Cretaceous, plateau ages (Baia de Arieş nappe, their samples 15 and 17, located near our sample AP44). The resetting of the hornblende argon system indicates elevated temperatures, although temperatures $>\sim 500{ }^{\circ} \mathrm{C}$ (McDougall and Harrison 1999) often quoted as closing temperatures are unlikely in view of the metamorphic grade of the Vidolm nappe marbles of suspected Mesozoic age. This thermal event could be either related to heat transfer from the obducted hot ophiolitic unit with island-arc signature, that is, the Transylvanian nappe or, alternatively, from heating that followed tectonic burial of the Vidolm continental basement underneath this ophiolitic unit during arc-continent collision in the Late Jurassic.

Because of the subsequent Cretaceous-age tectonometamorphic overprint, our fission-track data do not record sufficient information about this Jurassic event. Hence, we have to rely on geological information for interpreting this early thermal history. Should heating following tectonic burial of the Vidolm continental basement underneath the Transylvanian ophiolites be responsible for this Late Jurassic thermal event, the Vidolm nappe would have remained buried underneath the Transylvanian nappe all the time until subduction continued, or resumed, in Early Cretaceous times. However, this scenario is rather unlikely in view of the field observation that Upper Jurassic to Lower Cretaceous carbonates stratigraphically overlie both the island-arc volcanics of the Transylvanian ophiolites as well as the continental basement and suspected Mesozoic cover of the underlying Vidolm nappe. Should obduction of a young and hot ophiolite have been the heat source, we would expect rapid cooling of both ophiolites and the underlying Vidolm nappe soon after obduction. This is the scenario we prefer (see Fig. 10).

Unfortunately, a definitive answer regarding the Late Jurassic scenario cannot be given because the elucidation of the primary, that is, Jurassic-age, structural position and
Fig. 10 Temperature-time diagram discussing possible interpretations of the thermal evolution of the different units in the south-eastern Apuseni Mountain, as inferred from the fission-track data

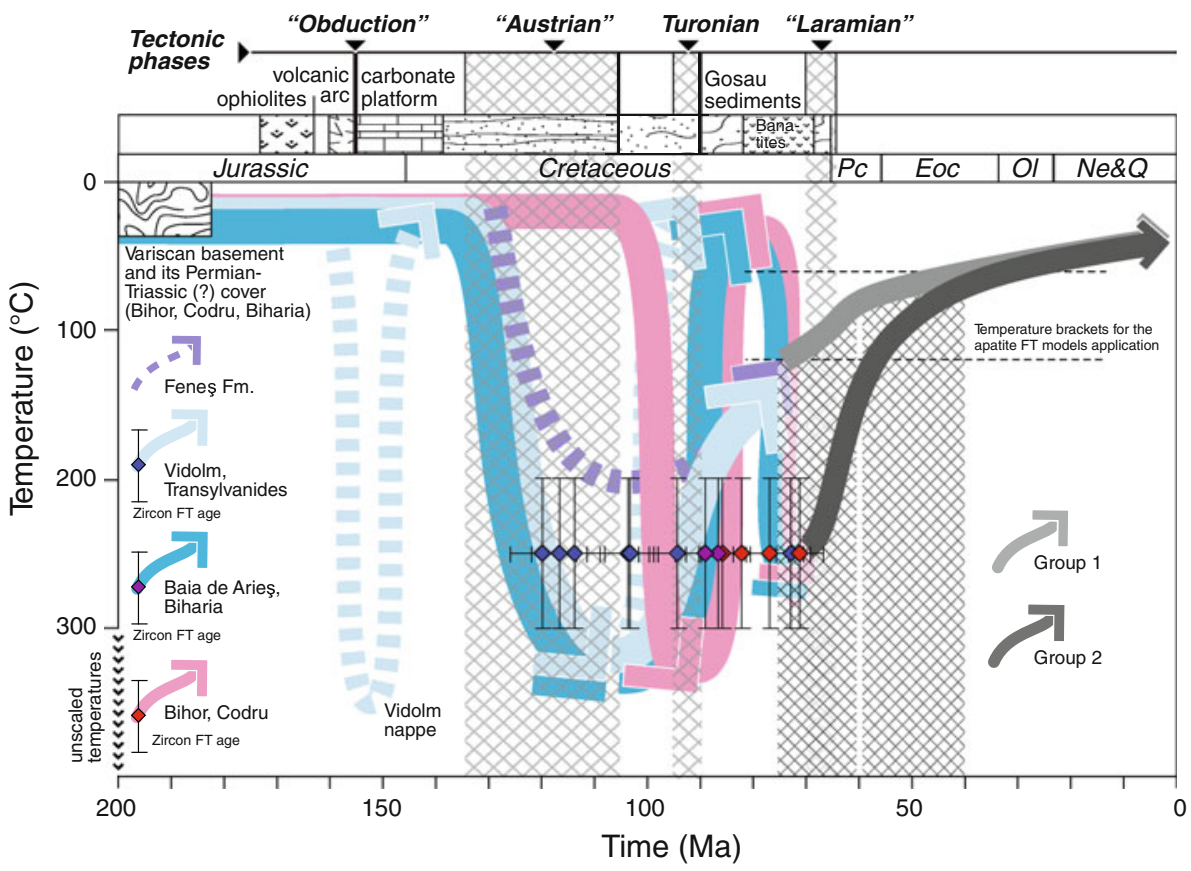


tectonic relationship of the Jurassic oceanic island-arc complex of the Transylvanides in respect to the underlying continental Vidolm nappe is difficult in the area. This is due to (1) relatively poor outcrop conditions of the contact areas, (2) heavy reworking of such contacts during later tectonic stages and (3) widespread burial of the contact below the Cretaceous cover, except for a small area in the Trascau Mountains (Figs. 2, 3). Figure 11a, b and c illustrate the contact of the Transylvanide volcanics with the continent-derived basement and its suspected Mesozoic cover (marbles of the Vidolm nappe; Fig. 11a) as observed along the eastern slope of the Trascău Mountains near Izvoarele (Fig. 3). Map pattern (Ilie 1932) and own observations indicate that this contact was near-isoclinally folded, then unconformably overlain by the Upper Cretaceous Rameţi flysch (Fig. 3) and in places again reactivated by Late Cretaceous 'Laramian' thrusting (Fig. 4). Since the work of Săsăran (2005) and Bucur and Săsăran

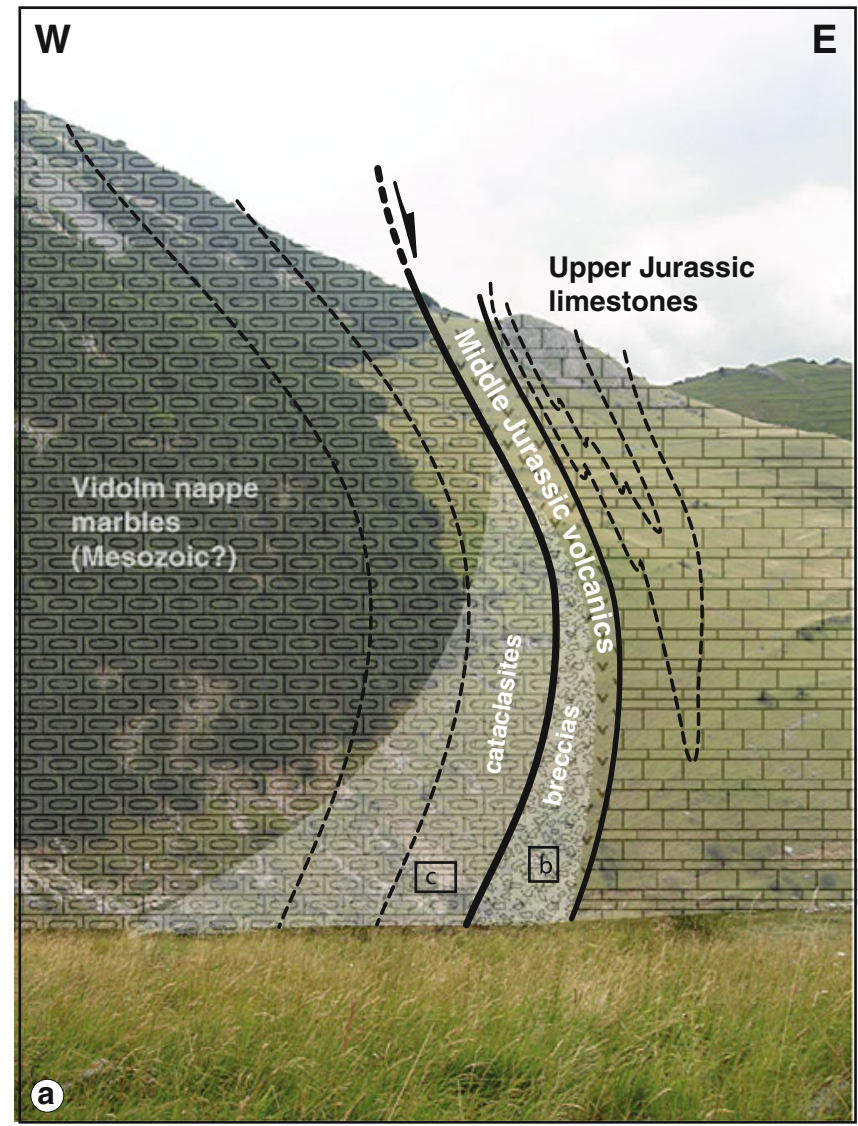

Fig. 11 Structural observations along the eastern slope of the Trascău Mountains $1 \mathrm{~km}$ west of Izvoarele (uppermost Aiud river valley; locality indicated in Figs. 3, 4). a Folded tectonic contact between the Transylvanian nappes, consisting of Middle Jurassic volcanics and their sedimentary cover (Upper Jurassic Aptychus limestone) to the east and the marbles of the Vidolm nappe (Mesozoic?) to the west. This Jurassic-age thrust was near-isoclinally folded (see syncline formed by the Aptychus beds) during the Early
(2005) makes it clear that Upper Jurassic to Lower Cretaceous carbonates sealed an already existing tectonic contact between the oceanic island-arc complex and the underlying Vidolm nappe, the tectonic contact shown in Fig. 11a must be Jurassic in age. Figure 11a shows this tectonic contact in the western limb of a near-isoclinal synform near Izvoarele that formed during Early Cretaceous orogeny (see Figs. 3, 4 for location). The basic volcanics are tectonically brecciated near the contact (Fig. 11b) while the marbles of the Vidolm nappe show intensive ductile deformation (Fig. 11c), locally also cataclastically overprinted. Nearby, the stratigraphic nature of the contact between the volcanics and their stratigraphic cover (Upper Jurassic Aptychus limestone; Săsăran 2005) can be observed (Fig. 11d).

Unfortunately, we could not reveal sense of tectonic transport for the Jurassic-age contact. Nowhere could we observe a preserved metamorphic sole and/or an ophiolitic

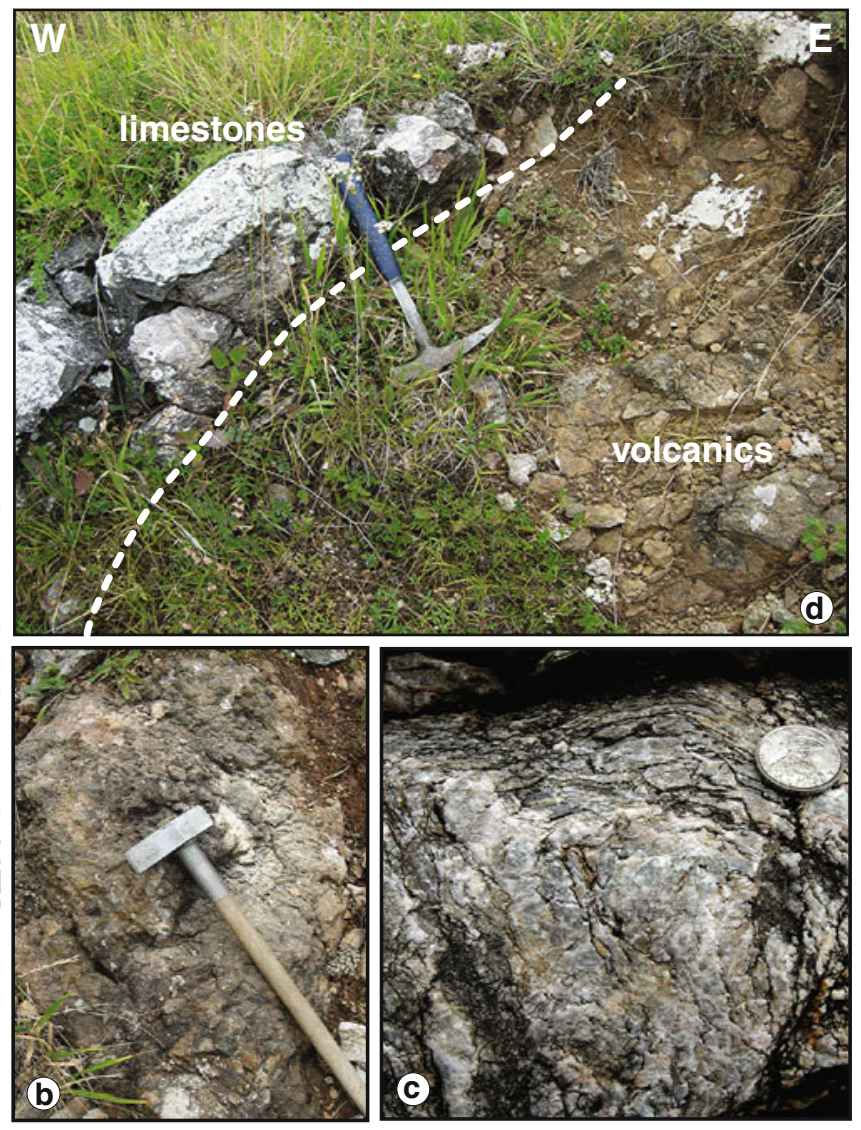

Cretaceous 'Austrian' phase; these folds are cut by the transgression of the Upper Cretaceous Rameţi Formation cropping out immediately east of this picture at the locality Izvoarele (Ilie 1932). b Brecciated Middle Jurassic volcanics near Jurassic-age tectonic contact (see Fig. 11a). c Refolded foliated (Mesozoic?) marbles of the Baia de Arieş nappe near the Jurassic-age tectonic contact (see Fig. 11a). d Upper Jurassic Aptychus limestone unconformably covering Jurassic volcanics, Coltesti village north of Izvoarele (Fig. 3) 
mélange. The low metamorphic grade of the marbles and the absence of high-pressure minerals indicate that the Jurassic-age subduction of the lower plate (Biharia nappe system) underneath the volcanics cannot have been substantial. Speculatively, we propose a marginal basin setting with obduction in a general strike-slip setting (Fig. 12a). Retrodeformation of the polyphase overprint at the eastern margin of the Trascau Mountains (Fig. 11a) clearly reveals that the future Biharia nappe system must have been in the footwall of the Transylvanian ophiolites. Provided that the correlation of the Transylvanian ophiolites with the East Vardar ophiolites proposed by Schmid et al. (2008) is correct, and that the contact shown in Fig. 11a is indeed related to obduction, this supports the correlation of the Biharia nappe system with the Dacia Mega-Unit that also includes the Serbo-Macedonian massif.

\section{Early Cretaceous ('Austrian’) orogeny}

Based on biostratigraphic evidence, the Early Cretaceous orogeny in the Apuseni Mountains started during the Barremian ( $130 \mathrm{Ma})$, that is, with the onset of syntectonic sedimentation recorded by the Feneş Formation, or possibly even earlier (136 Ma) given the onset of similar wildflysch formation in the Bucovinian nappes in the East Carpathians during the Hauterivian (Săndulescu 1984). Parts of the Vidolm nappe and the Transylvanides are covered by Upper Albian post-tectonic cover. This constrains the 'Austrian' orogeny to the 136-105 Ma time span on biostratigraphic grounds.
At first sight, the most surprising result of our zircon fission-track data is that the Jurassic volcanics and their Upper Jurassic to Lower Cretaceous cover, presently found in the structurally highest position, were at temperatures higher than $\sim 250{ }^{\circ} \mathrm{C}$ before the 135-98 Ma time interval. This is indicated by the fission-track central ages (Table 1; Fig. 3; intervals given always include $1 \sigma$ error) that reflect cooling from this Early Cretaceous event through the mean effective closure temperature of $250 \pm 50{ }^{\circ} \mathrm{C}$ (Fig. 10). Since the youngest sediments overlying the Jurassic volcanics, whose FT ages were reset are of Early Cretaceous age (Early Valanginian, Săsăran 2005; Bucur and Săsăran 2005), this time interval must indicate cooling from an Early Cretaceous event-and not from a Jurassic one-in the case of the Vidolm nappe. Assuming a geothermal gradient of $30^{\circ} \mathrm{C} / \mathrm{km}$, which is high for an evolving orogen, one deduces burial of the Transylvanides to a minimum of $8 \mathrm{~km}$. Since the thickness of the Lower Cretaceous sedimentary cover in this area is less than $1 \mathrm{~km}$ (Lupu et al. 1967), tectonic burial of the Transylvanides to a depth of at least $8 \mathrm{~km}$ must be invoked. Such burial must have occurred during Early Cretaceous ('Austrian') orogeny, in spite of the fact that the Transylvanides presently form the highest tectonic unit of the nappe edifice of the Apuseni Mountains. The three zircon fission-track central ages from the Vidolm nappe are slightly younger (112-96 Ma, Table 1). These cooling ages coincide with the onset of sedimentation of the post-tectonic cover that sealed the contact between Vidolm nappe and the Transylvanides in the Late Albian. Dallmeyer et al. (1999) report 118.2 \pm 0.3
Fig. 12 Sketch of the platetectonic evolution along a transect crossing Apuseni Mountains and Carpathians for the a latest Jurassic b late Early Cretaceous and $\mathbf{c}$ Late Cretaceous (after Schmid et al. 2008) latest Jurassic

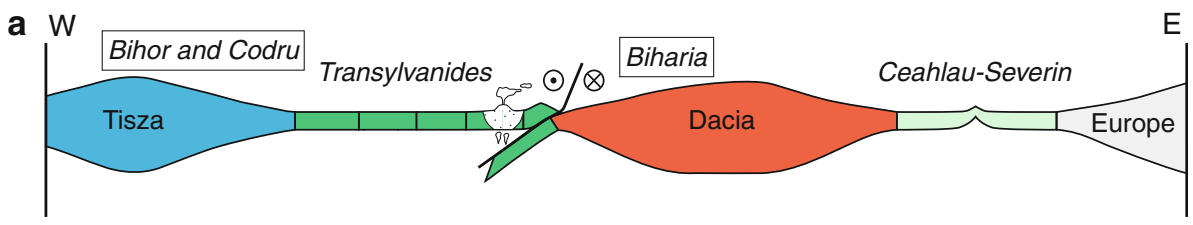

late Early Cretaceous
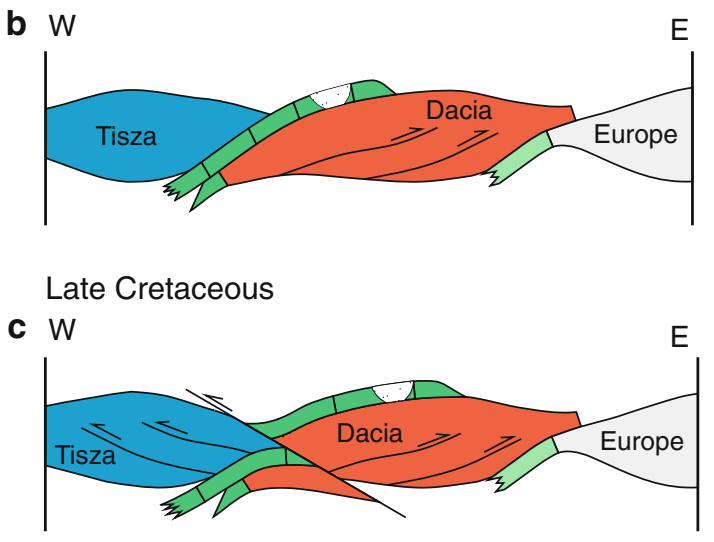
and $119.0 \pm 0.1 \mathrm{Ma}$ hornblende ${ }^{40} \mathrm{Ar} /{ }^{39} \mathrm{Ar}$ plateau ages (their samples 15 and 17, respectively) from samples located near our sample AP44, that is, in the Baia de Aries nappe, but still in the hangingwall of the top-NW to $-\mathrm{W}$ Highis-Biharia Shear Zone affecting the Biharia and Codru nappe systems.

We conclude that the Vidolm nappe and the Transylvanides were affected by this Lower Cretaceous tectonometamorphic event and became exhumed in Late Albian time (Fig. 10). As is evidenced from the reported Aptian hornblende ${ }^{40} \mathrm{Ar} /{ }^{39} \mathrm{Ar}$ plateau ages (Dallmeyer et al. 1999), the Baia de Arieş nappe and probably the structurally deeper Biharia nappe have also been part of the footwall of the 'Austrian' nappe system. The only difference with the overlying Vidolm nappe and the Transylvanides is that the Baia de Arieş and Biharia nappes have been exhumed later, probably following the Turonian tectonics (Fig. 10). Furthermore, our results indicate tectonic burial of the Transylvanides under a considerable tectonic overburden that has been eroded away since. Unfortunately, a structural study of the Biharia nappe system and the Transylvanides is still missing, except for a local study by Ellero et al. (2002), which reports polyphase deformation in the Feneş Formation. On the other hand, the large-scale scenario of this Early Cretaceous orogeny is rather well known from surrounding units (e.g. Kounov et al. 2010), and in the following, we discuss the thermal history in a regional tectonic framework.

Early Cretaceous 'Austrian' orogeny is widespread in all the internal units of the East and South Carpathians that belong to the Dacia Mega-Unit (e.g. Săndulescu 1984, Schmid et al. 2008). The Transylvanian nappes represent the highest tectonic unit in the East Carpathians, thrust eastwards (in present-day coordinates) over the Bucovinian, Subbucovinian and Infrabucovinian nappes (Dacia Mega-Unit, Fig. 12b, Săndulescu 1984, 1994; Schmid et al. 2008). According to Săndulescu (1994; his Fig. 4), the east-facing Transylvanian nappes of the East Carpathians, consisting of ophiolites (Hoeck et al. 2009) and detached Mesozoic sediments, find their root below the Bihor nappe system of the Apuseni Mountains. There is no stringent evidence from our zircon fission-track cooling ages, nor from the work of Dallmeyer et al. (1999), that an Early Cretaceous thermal event also affected the Codru and Bihor nappe systems (except for sample 34 of Dallmeyer et al. 1999, showing a plateau at $117 \mathrm{Ma}$ in a whole rock sample of Triassic siltstone whose interpretation is open to discussion). Based on this, and combined with regional arguments proposed by Schmid et al. (2008), we suggest that the Biharia nappe system, which underlies the Transylvanides, is part of the Dacia Mega-Unit (Figs. 1, 12). The Tisza Mega-Unit, however, only consisting of the Codru and Bihor nappe systems, escaped this Early Cretaceous thermal event. Given east-facing thrusting during
'Austrian' orogeny, our thermal data support the hypothesis that Tisza occupied an upper plate structural position during Early Cretaceous orogeny (Fig. 12b). According to this hypothesis, the Dacia mega-tectonic unit, of which the Biharia nappe system is a part, was underthrusted, together with the ophiolites, below the Tisza mega-tectonic unit during the 'Austrian' phase (Figs. 12b, 13a). This leads to the proposal that Early Cretaceous orogeny led to the closure of the South Apuseni-Transylvanian oceanic realm and its subduction underneath the Tisza Mega-Unit (Fig. 12b). Due to the later top-W thrusting, discussed below (Fig. 12c), the trace of this suture is not preserved at the present-day earth's surface. However, Schuller and Frisch (2006) report minor amounts of glaucophane, together with $\mathrm{Cr}$-spinel in one of their heavy mineral spectra obtained from the Gosau Group (Drocea basin of the Highiş Mountains).

According to this interpretation, the Barremian to Lower Aptian Feneş Formation (Lupu 1983), representing part of the cover of the Transylvanides (Fig. 3), must also have been involved in 'Austrian' top-E thrusting (Fig. 13a). This is supported by the FT data obtained for sediment sample AP35 that point to partial resetting of detrital zircons at temperatures lower than $250{ }^{\circ} \mathrm{C}$ (Fig. 10). Additionally, this is supported by the modelling of the apatite FT data from the Feneş Formation indicating a heating event between 120 and $100 \mathrm{Ma}$ to temperatures $>120^{\circ} \mathrm{C}$ (Figs. 9a, 10). Reported illite and chlorite crystallinity values show that these same sediments have been at temperatures between 150 and $200{ }^{\circ} \mathrm{C}$ (Ellero et al. 2002). The zircon detrital populations from Upper Cretaceous sediments (Gosau and Rameţi flysch, Fig. 5), showing youngest FT age peaks at around 96 and $97 \mathrm{Ma}$, respectively, testify to exhumation and erosion of a part of the source area immediately after the 'Austrian phase'. A similar

a Late Early-Cretaceous ("Austrian" phase)

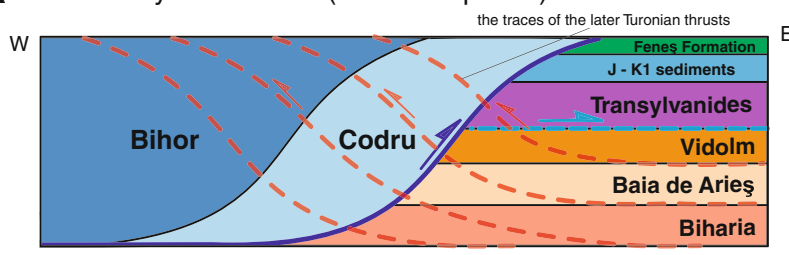

b Turonian ("Intra-Turonian" phase)

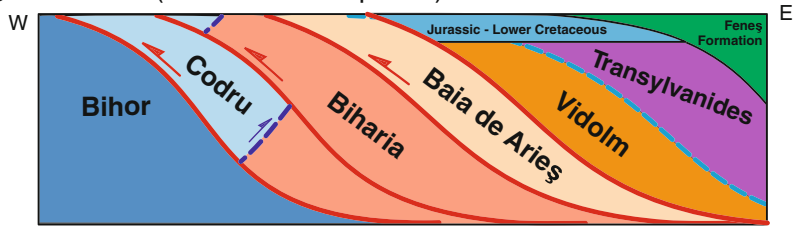

Fig. 13 Schematic sections trough the Eastern Apuseni Mountains representing the tectonic position of the major units during a late Early Cretaceous and $\mathbf{b}$ Turonian time 
young zircon detrital population (between 90 and $110 \mathrm{Ma}$ ) from the Gosau sediments in the Apuseni Mountains was also reported by Schuller (2004) and Schuller et al. (2009).

The tectonic scenario shown in Fig. 13a is additionally supported by the fact that the Baia de Arieş nappe must have experienced considerable heating during the 'Austrian phase' (hornblende plateau ages; Dallmeyer et al. 1999; their samples 15 and 17), while the Feneş Formation does not record temperatures much higher than some $200{ }^{\circ} \mathrm{C}$ (Fig. 13a). The structurally lowest Biharia nappe system was heavily deformed during a later phase of deformation (Fig. 13b) leading to the formation of the Highis-Biharia Shear Zone, as will be discussed below. The Bihor and Codru units, being in a hanging wall position during Early Cretaceous thrusting (Fig. 13a), only experienced deformation under low temperatures that did not reset the Palaeozoic ${ }^{40} \mathrm{Ar} /{ }^{39} \mathrm{Ar}$ ages reported by Dallmeyer et al. (1999).

In conclusion, our data support the hypothesis that (1) Early Cretaceous thrusting was east-facing (in present-day geographical coordinates) and (2) the Tisza Mega-Unit was in an upper plate position during such thrusting, associated with the final closure of the Transylvanian Ocean, a part of the East Vardar branch of Neotethys (Schmid et al. 2008), located between the Tisza and Dacia Mega-Units (Fig. 12b).

Cooling of the Vidolm nappe and the Transylvanides after the early Cretaceous orogeny

The timing for the onset of cooling of these two tectonic units to temperatures below $250{ }^{\circ} \mathrm{C}$ (Fig. 10) is constrained by the zircon fission-track central ages. The small age difference between the zircon FT central ages (including the $1 \sigma$ error) from the Transylvanides (135-98 Ma) and those from the basement of the Vidolm nappe (112-96 Ma) may reflect the different structural positions of these units during exhumation. The Vidolm nappe, being at a deeper structural level, may well have been exhumed later. Since the Baia de Arieş and Biharia nappes are in a lower structural position within the Biharia nappe system, they cooled below $\sim 250{ }^{\circ} \mathrm{C}$ after this time interval (Figs. 10, 13).

Unfortunately, our zircon FT data alone do not allow for quantitatively estimating the rate of this early post-tectonic denudation. However, since the age of the base of the sediments above the post-'Austrian' unconformity preserved in the south-eastern parts of Fig. 3 (Valea lui Paul Formation) is late Albian, parts of the Transylvanides must have been at or near the earth's surface some $105 \mathrm{Ma}$ ago. Hence, the parts of the Vidolm nappe together with the Transylvanides located in the north-eastern part of Fig. 3 must have initially cooled to a moderate temperature that, however, had to be higher than about $120{ }^{\circ} \mathrm{C}$ (the lower temperature limit of the apatite annealing window) at $105 \mathrm{Ma}$ (Figs 7, 8). Note that the samples collected for fission-track analysis from the Transylvanian and Vidolm nappes are in an area where these two tectonic units only exhibit tectonic contacts with the Upper Cretaceous posttectonic Gosau cover. This suggests that they may not have been exhumed to the surface before Cenozoic times (Fig. 10). This is independently confirmed by the apatite FT modelling (Figs. 7, 8).

We conclude that the parts of the Vidolm nappe and the Transylvanides initially cooled rapidly to near surface temperatures in Albian times (Fig. 10). Some of the samples located far below the base of the Cretaceous-age posttectonic cover, for example the Valea lui Paul, Gosau or Rameţi formations, however, must have remained at considerable depth until final exhumation that followed the younger Late Cretaceous orogenic event discussed below.

Thermal history during late Cretaceous (Turonian) orogeny

The zircon FT central ages obtained from the Biharia nappe (94-70 Ma) and from the Baia de Arieş nappe (101-69 Ma) are younger than those from the Vidolm nappe. This indicates that these rocks were not substantially exhumed after Early Cretaceous orogeny and remained above some $250{ }^{\circ} \mathrm{C}$, that is, quite deeply buried, during Turonian orogeny, whose timing is well constrained by stratigraphical data (Fig. 10). This is compatible with the sketch presented in Fig. 13. The samples from the Codru and Bihor nappe systems, which are part of the Tisza Mega-Unit, must have remained below some $250{ }^{\circ} \mathrm{C}$ after the Variscan cycle and before being heated during Late Cretaceous (Turonian) orogeny. Consequently, they show even younger zircon FT central ages (95-67 Ma; Late Cenomanian to Maastrichtian). Hence, these units must have been buried to temperatures above $250{ }^{\circ} \mathrm{C}$ slightly before, during or shortly after Turonian times (93.5-89.3 Ma; Figs. 10, 13b). According to kinematic indicators, observed during structural reconnaissance work, Turonian thrusting was top $\mathrm{W}$ to top NW in the Apuseni Mountains and led to the emplacement of the Biharia nappe system, including the previously emplaced Transylvanides, onto the Bihor and Codru nappe systems (Figs. 4a, 12c, 13b). This thrusting occurred under lower greenschist-facies conditions and was mainly accommodated within the Highis-Biharia Shear Zone (Pană and Erdmer 1994; Pană 1998; Dallmeyer et al. 1999) that affected the Biharia nappe and the Codru nappe system. The reported $\mathrm{K} / \mathrm{Ar}$ and ${ }^{40} \mathrm{Ar} /{ }^{39} \mathrm{Ar}$ ages from this east- to south-dipping low-grade shear zone in the metamorphic basement (Pană and Erdmer 1994; Pană et al. 2002) widely range between 400 and $75 \mathrm{Ma}$ (Soroiu et al. 1969; Pavelescu et al. 1975; Dallmeyer et al. 1999). This is likely to be due to incomplete resetting of pre-Alpine ages. Hence, 
this large age range is at least not incompatible with activity along this shear zone during Turonian orogeny.

In summary, we interpret heating of the Codru and the southern Bihor nappe to have resulted from tectonic burial during Late Cretaceous (Turonian) orogeny (Figs. 10, 13b). The formerly buried Vidolm nappe and overlying Transylvanides now occupied the structurally highest position within this newly formed $\mathrm{W}$-facing nappe stack. Therefore, they were not, or at least not substantially, reheated and stayed below $\sim 200{ }^{\circ} \mathrm{C}$, preserving their mid-Cretaceous zircon central ages (Figs. 10, 13b). The structurally deeper Biharia and Baia de Arieş nappes, on the other hand, reached temperatures higher than $250{ }^{\circ} \mathrm{C}$ during this event (Fig. 10). The relatively young age of one of the samples from the Baia de Arieş unit (AP41, yielding $73 \mathrm{Ma}$ ) could also result from heating by the nearby Late Cretaceous banatite intrusions (Figs. 3, 4a, 10) since we observed many banatite dykes near this sampling site.

Late cretaceous cooling and early evolution of the Gosau basins

Post-Turonian (post $89 \mathrm{Ma}$ ), but pre-Cenozoic, cooling to temperatures below $\sim 250{ }^{\circ} \mathrm{C}$ is indicated by the zircon FT central ages of a number of samples from the Bihor, Codru and Biharia nappe systems (Fig. 10). These tectonic units, amongst others, are reported to have been the source areas of the Gosau basin sediments in the area during Late Cretaceous times (Schuller and Frisch 2006). Since the zircon FT cooling ages from the source areas overlap with the time of sedimentation (Fig. 4a), this suggests fast exhumation and erosion at the basin margins (Fig. 10).

Constraints on the denudation rate for post-Turonian times are provided by the analysis of statistically separated zircon detrital populations from the Gosau Group sample AP45 (Fig. 5). This sample was collected in the turbiditic Upper Gosau Subgroup, which has a Campanian to Maastrichtian (75-65 Ma) age (Schuller et al. 2009). The younger detrital population in this sample peaks at $97 \mathrm{Ma}$, that is, $\sim 20 \mathrm{Ma}$ earlier than the age of deposition and $\sim 15 \mathrm{Ma}$. It also predates the zircon FT central ages obtained from the present-day outcropping basement (Bihor, Codru and Biharia nappes, Figs. 3, 5) that is covered by Gosau deposits nearby. A rough estimation of the denudation rate, assuming a $30^{\circ} \mathrm{C} / \mathrm{km}$ thermal gradient, gives rates of around $0.5 \mathrm{~mm} / \mathrm{a}$.

The modelling of the apatite data from the Cenomanian to Maastrichtian (100-65 Ma) Rameţi Formation (sample AP46; Fig. 9) infers a cooling interval that roughly coincides with the time of deposition. Would the sampled sandstones belong to the younger part of the formation ( $\leq 85 \mathrm{Ma}$, Fig. 9a), this would indicate relatively fast cooling of the source area according to the modelling.
Alternatively, should the sampled sediment be older than $\sim 85 \mathrm{Ma}$, the modelled cooling could in fact follow a heating event in the basin that took place very soon after deposition (Fig. 9b). However, this would only be possible if the deposition of the Rameţi Formation would be related to the evolution of a syn-tectonic basin, which quickly became involved in deformation.

Fast initial cooling is particularly indicated for basement samples AP36 and AP44. These samples are in close proximity to the Gosau sediments and they hence can be assumed to have been very near the earth's surface at or soon after $95 \mathrm{Ma}$ ago, before being re-heated and thereafter passing the apatite partial annealing zone while cooling again (Fig. 8b).

In the case of the Rameţi Formation, relatively fast denudation, related to active tectonics in the source area, is also evidenced by the existence of large olistoliths found in this late Cretaceous turbiditic basin (Fig. 14, Bleahu et al. 1981). Theoretically, the slope of the age-altitude curve could give a good estimate of the denudation rate. However, due to a complex cooling history that depends on the geographical location of the samples that did not preserve their original tectonic position due to later tectonism, a positive age-altitude relationship could not be revealed (Fig. 15).

We now discuss evolution and tectonic setting of the Gosau basins in the light of the discussion presented above. It is clear that the base of the Gosau basins unconformably overlies the nappe pile formed during Turonian orogeny. This implies substantial denudation of the source areas starting at the end of the Turonian (89 Ma), together with initial subsidence of the basins (Balintoni 1994; Willingshofer et al. 1999; Schuller 2004). Note that Schuller (2004) emphasized the important distinction between a Lower and an Upper Gosau Subgroup.

The Lower Gosau Subgroup, deposited in shallow water, is characterized by slow subsidence rates. Early studies related the initial formation of these basins to in situ orogenic wedge collapse following thickening of the continental crust (e.g. Willingshofer et al. 1999). Others related the deposition of the Late Cretaceous sediments in the Apuseni Mountain to the evolution of the Transylvanian Basin that is in a back-arc (e.g. Huismans et al. 1997; Fodor et al. 1999; Horvath et al. 2006; Cloetingh et al. 2006) or fore-arc (Schuller 2004 and Schuller et al. 2009) position with respect to subduction in the East Carpathians. A third possibility is indicated by the now generally accepted scenario that led to banatite magmatism, which is partly coeval with Gosau sedimentation in the Apuseni. This magmatism is known to be part of the ApuseniBanat-Timok-Sredna Gora belt that can be followed all the way to Bulgaria and that can be restored to a straight SE-NW-striking belt by retro-deformation of Cenozoic 

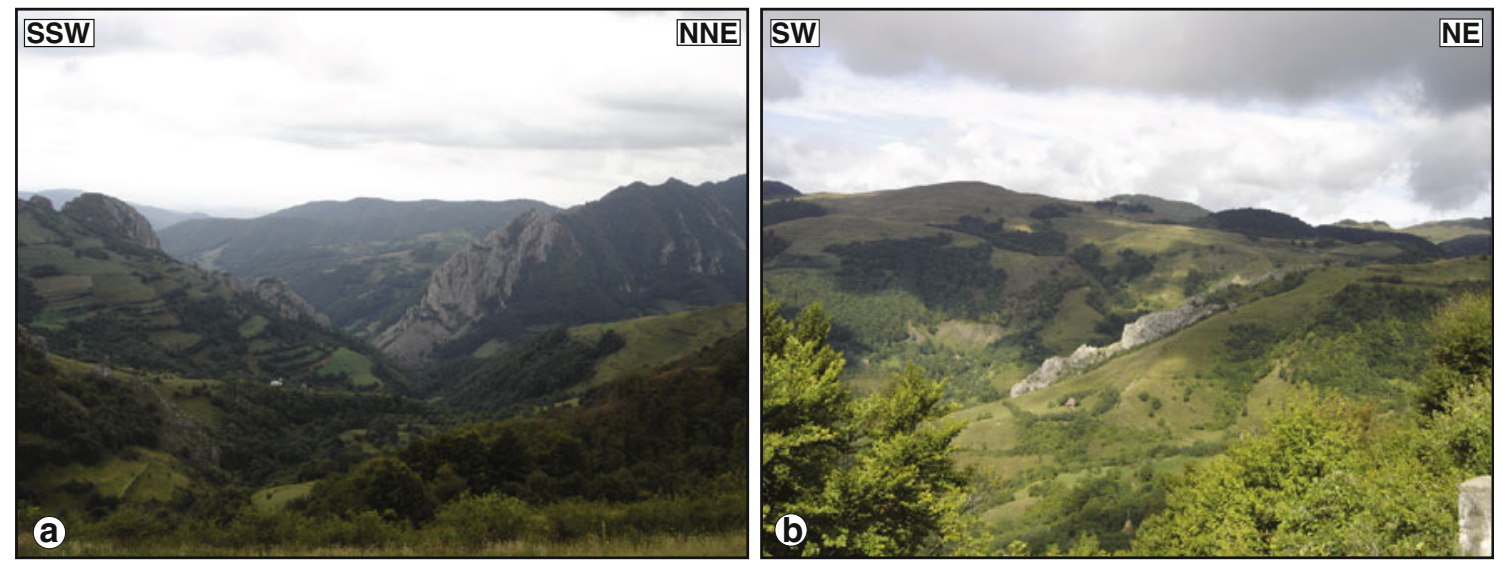

Fig. 14 Kilometre (a) to metre- (b) scale olistolith blocks of the Upper Jurassic platform carbonates in the turbiditic succession of the Rameţi Formation west of Rimeț (Fig. 3)

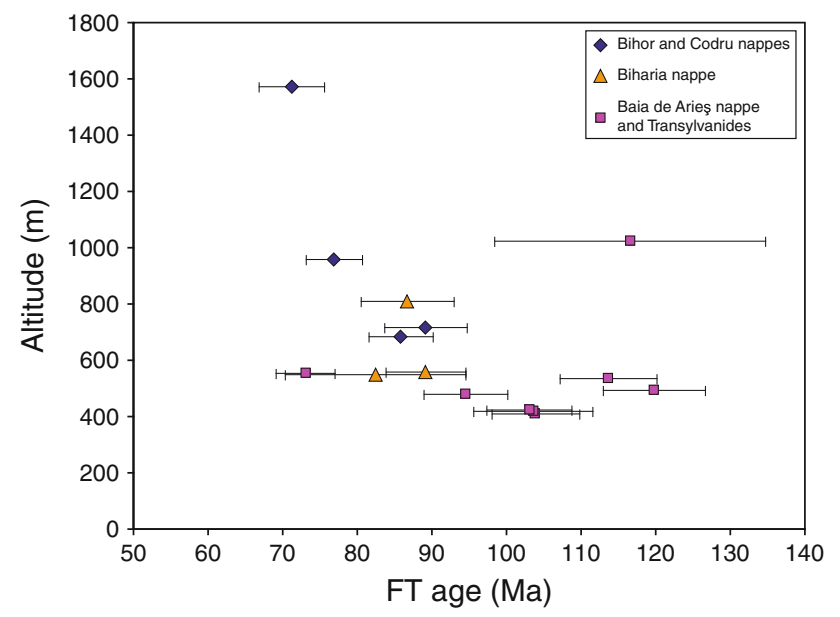

Fig. 15 Zircon FT central ages from the major tectonic units versus their altitude. No correlation is apparent

rotations (Fügenschuh and Schmid 2005). This belt is generally seen as a manifestation of back-arc magmatism related to the northward subduction of Neotethys below the Rhodopes and the Tisza-Dacia Mega-Units, that is, the European margin (e.g. von Cotta 1864; Berza et al. 1998; Heinrich and Neubauer 2002; von Quadt et al. 2005; Zimmerman et al. 2008). Sedimentation of the Lower Gosau Subgroup started between some 90 and $84 \mathrm{Ma}$ (Schuller 2004) and hence largely overlaps with the 83-72 Ma age interval given for magmatic activity in the Apuseni Mountains (Zimmerman et al. 2008). Our apatite fission-track modelling of sample AP45 (Upper Gosau Subgroup; Fig. 9) supports elevated heat flow during the time of Gosau sedimentation; the temperatures must have exceeded $120{ }^{\circ} \mathrm{C}$ during the late Cretaceous as is suggested by the resetting of the apatite FT age in sample AP45. Since only a maximum of $3 \mathrm{~km}$ of sedimentary overburden can be expected for the Gosau basins (Schuller 2004), increased heat flow is indicated. This fits well with the elevated thermal gradients reported by Schuller et al. (2009) for the time of deposition of the Gosau basin sediments, based on modelling vitrinite reflection data and subsidence analysis.

Concluding, we favour extensional denudation of the Turonian orogen due to the back-arc extension associated with the 'banatitic' magmatic activity related to the subduction of Neotethys along strike of the Hellenidic-Dinaridic orogen.

Late campanian to Maastrichtian ('Laramian') orogeny and late-stage evolution of the Gosau basins

This third Cretaceous-age compressional event affected the entire Romanian Carpathian belt. Starting during the Late Campanian, it culminated in the Maastrichtian (Săndulescu 1984, 1994). The onset of massive subsidence leading to the deposition of the Upper Gosau Subgroup (Schuller et al. 2009) during the latest Campanian to Maastrichtian coincided with the 'Laramian' orogeny. This and the fact that such late-stage subsidence only affected the southern (Schuller 2004), but not the northern Apuseni Mountains that lack a 'Laramian' tectonic overprint, points to a syn-orogenic character of the Upper Gosau Subgroup, including the Bozes Flysch located between Deva and Alba Julia (Fig. 2). Note, however, that the model proposed by Schuller (2004) and Schuller et al. (2009), arguing for the deposition of the Bozes Flysch in a trench related to the subduction of the Transylvanian Ocean during latest Cretaceous times is at odds with our interpretation of the data, which indicates suturing of the Tisza and Dacia Mega-Units during final closing of the Transylvanian Ocean at the end of the Early Cretaceous. Their model is also in conflict with larger-scale considerations by other authors (e.g. Csontos and Vörös 2004; Schmid et al. 2008; Matenco et al. 2010). 
Some constraints regarding cooling rates during deposition of the Upper Gosau Subgroup (latest Campanian to Maastrichtian) sediments are obtained from apatite FT modelling. Moderate cooling rates to temperatures below $120{ }^{\circ} \mathrm{C}$ between 75 and $60 \mathrm{Ma}$, that is, during the final stages of and slightly beyond the deposition of the Gosau basins, whose age spans the 90-65 Ma age interval (Schuller 2004), is revealed by the modelling performed on three samples from the Baia de Arieş and Vidolm nappes (AP22 AP24 and AP41) and on one sample taken at high altitude form the Bihor nappe (AP08) in the NW part of the area (see Figs. 3, 7 and cooling curve for Group 1 in Fig. 10). Modelling points to moderate denudation in the source area during the deposition of the Upper Gosau Subgroup (Campanian to Maastrichtian; Schuller 2004) in the case of these Group 1 samples that started to cool earlier compared to the Group 2 samples (compare Figs. 7, 8); hence, they must have been nearer to the earth's surface in latest Cretaceous times.

Our fission-track data do not provide evidence for reheating caused by tectonic burial during this end-Cretaceous compression. This is in line with the apatite fissiontrack data reported from the Gosau sediments in the southern Apuseni by Schuller (2004) and Schuller et al. (2009), and additionally, with field evidence that suggests moderate amounts of shortening during the 'Laramian' event (Fig. 4) when compared to the massive shortening leading to nappe formation during the Early Cretaceous and Turonian orogenies (Huismans et al. 1997; Ellero et al. 2002; Schuller 2004). However, the effects of this latest Cretaceous compressive event, together with further compression during the Cenozoic, are instrumental for understanding the Cenozoic thermal and tectonic evolution discussed below.

\section{Cenozoic thermal evolution}

Fission-track data and modelling indicate ongoing cooling during the Early Cenozoic but no evidence for reheating events (Fig. 10). Modelling of the apatite data of several samples from the Bihor, Codru and Biharia nappe systems show relatively slow (compared to other orogens) cooling through the apatite FT partially annealing zone (120$60{ }^{\circ} \mathrm{C}$ ) between 60 and $40 \mathrm{Ma}$, further decelerating thereafter (Figs. 8, 10, Group 2). Some samples from Baia de Arieş, Vidolm nappes and the highest sample taken form the Bihor nappe also show very slow cooling during this same time interval (Figs. 7, 10, Group 1). The modelling of a sample from the Upper Gosau deposits (AP45), on the other hand, shows rapid cooling at around $50 \pm 5 \mathrm{Ma}$. The cooling was probably related to erosion that accompanied and/or followed 'Laramian' thrusting. Merten et al. (2011), who investigated the low-temperature thermal history of the Apuseni Mountains by combining apatite fission-track analysis with U-Th/He thermochronology, propose cooling to be caused by erosional denudation that followed Late Cretaceous, that is, 'Laramian' doming of the Bihor nappe system in the central Apuseni Mountains (high elevation Gilău Mountain range, Fig. 2). Furthermore, these authors revealed two additional compressional pulses in Early Eocene and Early Oligocene times by thermal modelling and structural investigations (near the Mezes thrust in the north-eastern most Apuseni Mountains, see Fig. 2).

We regard Late Cretaceous doming, followed by erosion of the Apuseni Mountains as the most plausible cause for slow cooling of our samples during the Early Cenozoic. This updoming led to an angular unconformity at the base of the Paleogene Jibou Formation, above Gosau basin deposits or the basement of the Biharia nappe system and located at the eastern flank of the structural dome of the Gilău Mountains (Fig. 2). The continental deposits of the Palaeocene to Lower Eocene Jibou Formation provide clear evidence for uplift and erosion that followed 'Laramian' shortening (Ciulavu et al. 2000; Schuller 2004; Merten et al. 2011).

Since the middle Eocene, the rocks presently exposed at the surface remained at temperatures below some $60{ }^{\circ} \mathrm{C}$. Their further thermal evolution is therefore not detectable by the FT method alone (Fig. 10). Nevertheless, some offsetting of the apatite FT ages across older thrust and strike-slip faults could suggest some post-Eocene reactivations of such structures as normal faults (Fig. 4b). These movements could be related to some of the extensional phases reported for the Transylvanian Basin in Mid-Miocene times (e.g. Huismans et al. 1997; Ciulavu et al. 2000; Krézsek and Bally 2006).

\section{Conclusions}

The new zircon FT data from the Eastern Apuseni Mountain show that the Biharia nappe system and the overlying Jurassic ophiolites, including their Jurassic to Lower Cretaceous sedimentary cover, must have been buried to a minimum of $8 \mathrm{~km}$ during late Early Cretaceous times. This burial is interpreted to have occurred during the late stages of under-thrusting of these units as parts of the Dacia Mega-Unit below the Tisza Mega-Unit (i.e. the future Codru and Bihor nappe systems) that formed the upper plate during Early Cretaceous ('Austrian') east-facing orogeny. This collisional event led to the closure of the East Vardar Neotethys branch of which the Transylvanian ophiolites are a part.

Younger, that is, Turonian to Campanian (95-71 Ma), zircon FT cooling ages were obtained from the Bihor and 
Codru nappe systems, that is, parts of the Tisza Mega-Unit, as well as from the Biharia and Baia de Arieş nappes, which represent the structurally lowest parts of the Dacia Mega-Unit. These cooling ages record erosional and partly extensional denudation that immediately followed a younger, that is, Turonian, top-NW event. This thrusting led to the overall geometry of the present-day nappe stack in the Apuseni Mountains. The Vidolm nappe and the overlying Transylvanides escaped reheating during this second Cretaceous event since they now occupied the highest tectonic position.

Zircon FT ages, combined with thermal modelling of the apatite FT data, show that relatively rapid post-tectonic cooling of the area during the Late Cretaceous. This was followed by slower cooling across the $120^{\circ}-60^{\circ} \mathrm{C}$ temperature interval during latest Cretaceous to earliest Paleogene times (75-60 Ma). Cenozoic-age slow cooling (60-40 Ma) was probably related to erosional denudation postdating 'Laramian' large-scale updoming.

Acknowledgments This study was funded by the Geological Institute of the Basel University and the Swiss National Science Foundation (projects 'Tisza' Nrs. 200021-101883/1 and 200020109278/1). The authors would like to thank Ioan Balintoni, Ioan Bucur and Emanoil Săsăran from the Babeş-Bolyai University (ClujNapoca), Mircea Săndulescu (Bucharest), as well as Volker Schuller (Tübingen) for introducing us to the Apuseni geology. We shared many discussions with all of them, as well as with Bernhard Fügenschuh, Martin Reiser (Innsbruck) and Liviu Matenco (Amsterdam). Daniel Bernoulli is thanked for his help that greatly improved the manuscript. Also, the constructive reviews of Volker Schuller and Franz Neubauer are gratefully acknowledged.

\section{References}

Balc R, Suciu-Krausz E, Borbei F (2007) Biostratigraphy of the Cretaceous deposits in the Western Transylvanides from Ampoi Valley (Southern Apuseni Mountains, Romania). Studia Universitatis Babeş-Bolyai Geol 52:37-43

Balintoni I (1994) Structure of the Apuseni Mountains. In: ALCAPA II field guidebook "South Carpathians and Apuseni Mountains". Romanian J Tectonics and Regional Geol 75:37-58

Balintoni I (1997) Geotectonica terenurilor metamorfice din Romania. Editura Carpatica, Cluj-Napoca; 176 pp

Balintoni I, Iancu V (1986) Lithostratigraphic and tectonic units in the Trascău Mountains, north of Mânăstirea Valley. DS Ins Geol Geofiz 70-71(5):45-56

Balintoni I, Balica C, Cliveţi M, Li L-Q, Hann HP, Chen Fukun, Schuller V (2009) The emplacement age of the Muntele Mare Variscan granite (Apuseni Mountains, Romania). Geol Carpathica 60:495-504

Balintoni I, Balica C, Ducea MN, Zaharia L, Chen Fukun, Cliveţi M, Hann HP, Li L-Q, Ghergari L (2010) Late Cambrian-Ordovician northeastern Gondwanan terranes in the basement of the Apuseni Mountains, Romania. J Geol Soc Lond 167:1131-1145

Balla Z (1987) Tertiary paleomagnetic data for the CarpathoPannonian region in the light of Miocene rotation kinematics. Tectonophysics 139:67-98
Berza T, Constantinescu E, Vlad SN (1998) Upper Cretaceous magmatic series and associated mineralization in the CarpathianBalkan orogen. Resour Geol 48:291-306

Bleahu M, Dimian M (1967) Stratigraphic and tectonic studies in Feneş-Ighiel-Întregalde area (Metaliferi Mountains). Dări de Seamă ale Comitetului de Stat Geologic, LIII 1:281-304 (in Romanian)

Bleahu M, Lupu M, Patrulius D, Bordea S, Stefan A, Panin S (1981) The Structure of the Apuseni Mountains. Guide to Excursion B3. 12th Carpatho-Balkan Geological Association Congress, Bucharest, Romania. Institute of Geology and Geophysics, Bucharest, Guidebook 23, pp 107

Bleahu M, Soroiu M, Cătilina R (1984) On the Cretaceous tectonicmagmatic evolution of the Apuseni Mountains as revealed by K-Ar dating. Rev Roum Phys 29:123-130

Bortolotti V, Nicolae I, Marroni M, Pandolfi L, Principi G, Saccani E (2002) Geological and petrological evidences for Jurassic association of ophiolite and Island arc volcanics in the South Apuseni Mountains (Romanian Carpathians). Int Geol Rev 44:938-955

Brandon MT (1992) Decomposition of fission-track grain-age distributions. Am J Sci 292:535-564

Brandon MT, Roden-Tice MK, Garver JI (1998) Late Cenozoic exhumation of the Cascadia accretionary wedge in the Olympic Mountains, northwest Washington State. Geol Soc Am Bull 110:985-1009

Bucur I, Săsăran E (2005) Micropaleontological assemblages from the upper Jurassic-lower Cretaceous deposits of Trascău Mountains and their biostratigraphic significance. Acta Paleontologica Romaniae 5:27-38

Burchfiel BC (1980) Eastern European Alpine system and the Carpathian orocline as an example of collision tectonics. Tectonophysics 63:31-61

Carlson DW, Donelick RA, Ketcham RA (1999) Variability of apatite fission-track annealing kinetics, I. Experimental results. Am Min 84:1213-1223

Ciulavu D, Dinu C, Szakacs A, Dordea D (2000) Neogene kinematics of the Transylvanian basin (Romania). AAPG Bul 84:1589-1615

Cloetingh S, Bada G, Matenco L, Lankreijer A, Horváth F, Dinu C (2006) Modes of basin (de)formation, lithospheric strength and vertical motions in the Pannonian-Carpathian system: inferences from thermo-mechanical modelling. In: Gee DG, Stephenson RA (eds) European lithosphere dynamics. Geol Soc London Memoirs 32:207-221

Corrigan JD (1993) Apatite fission-track analysis of Oligocene strata in South Texas, USA: testing annealing models. Chem Geol 104:227-249

Csontos L, Vörös A (2004) Mesozoic plate tectonic reconstruction of the Carpathian region. Paleogeogr Paleoclimatol Paleoecol 210:1-56

Dallmeyer RD, Pană DI, Neubauer F, Erdmer P (1999) Tectonothermal evolution of the Apuseni Mountains, Romania: resolution of Variscan versus Alpine events with ${ }^{40} \mathrm{Ar} /{ }^{39} \mathrm{Ar}$ ages. J Geol 107:329-352

de Broucker G, Mellin A, Duindam P (1998) Tectono-stratigraphic evolution of the Transylvanian Basin pre-salt sequence Romania. In: Dinu C, Mocanu VH (eds) geological structure and hydrocarbon potential of the Romanian area, Bucharest Geoscience Forum 1:36-69

Dimitrescu R (1985) Early Caledonian event in the pre-Alpine metamorphic assemblages of the Romanian Carpathian. Acta Mineral Petrogr Szeged 27:59-70

Dumitru TA (1995) A new computer automated microscope stage system for fission track analysis. Nucl Tracks Radiat Meas 21:575-580 
Ellero A, Leoni L, Marroni M, Nicolae I, Pandolfi L, Sartori F (2002) Deformation and metamorphism in the Feneş Nappe (southern Apuseni Mountains, Romania). C. R Geoscience 334:347-354

Filipescu S (2001) Cenozoic lithostratigraphic units in Transylvania. In: Bucur I, Filipescu S, Săsăran E, Field Trip Guide, 4th Regional Meeting IFAA 75-92

Fodor L, Csontos L, Bada G, Györfi I, Benkovics L (1999) Tertiary tectonic evolution of the Pannonian Basin system and neighbouring orogens: a new synthesis of palaeostress data. In: Durand B, Jolivet L, Horváth F, Séranne M (eds) The Mediterranean Basins: Tertiary extension within the Alpine Orogen. Geol Soc London Special Publ 156:295-334

Fügenschuh B, Schmid SM (2005) Age and significance of core complex formation in a very curved orogen: evidence from fission track studies in the South Carpathians (Romania). Tectonophysics 404:33-53

Galbraith RF, Green PF (1990) Estimating the component ages in a finite mixture. Nucl Tracks Radiat Meas 17:197-206

Galbraith RF, Laslett GM (1993) Statistical models for mixed fissiontrack ages. Nucl Tracks Radiat Meas 21:459-470

Gallagher K, Sambridge M (1994) Genetic algorithms: a powerful tool for large-scale nonlinear optimization problems. Comput Geosci 20:1229-1236

Garver JI, Soloviev AV, Bullen ME, Brandon MT (2000) Towards a more complete record of magmatism and exhumation in continental arcs using detrital fission track thermochronometry. Phys Chem Earth Part A 25:565-570

Gleadow AJW, Duddy IR (1981) A natural long-term annealing experiment for apatite. Nucl Tracks 5:169-174

Gleadow AJW, Duddy IR, Green PF, Lovering JF (1986) Confined fission track lengths in apatite: a diagnostic tool for thermal history analysis. Contrib Mineral Petrol 94:405-415

Green PF, Duddy IR (1989) Some comments on paleotemperature estimation from apatite fission track analysis. J Petrol Geol 12:111-114

Gröger HR, Fügenschuh B, Tischler M, Schmid SM, Foeken JPT (2008) Tertiary cooling and exhumation history in the Maramures area (internal eastern Carpathians, northern Romania): thermochronology and structural data. Geol Soc Lond Spec Publ 298:169-195

Györfi I, Csontos L, Nagymarosy A (1999) Early Tertiary structural evolution of the border zone between the Pannonian and Transylvanian Basins. In: Durand B, Jolivet L, Horváth F, Séranne M (eds) The Mediterranean basins: tertiary extension within the Alpine Orogen. Geol Soc London Special Publ 156:251-267

Haas J, Pero S (2004) Mesozoic evolution of the Tisza Mega-unit. Int J Earth Sci 93:297-313

Heinrich CA, Neubauer F (2002) Cu-Au-Pb-Zn-Ag metallogeny of the Alpine-Balkan Carpathian-Dinaride geodynamic province. Mineral Dep 37:533-540

Hoeck V, Ionescu C, Balintoni I, Koller F (2009) The Eastern Carpathians "ophiolites" (Romania): remnants of a Triassic ocean. Lithos 108:151-171

Horvath F, Bada G, Szafian P, Tari G, Adam A, Cloetingh S (2006) Modes of basin (de)formation, lithospheric strength and vertical motions in the Pannonian-Carpathian system: inferences from thermomechanical modeling. In: Gee DG, Stephenson RA (eds) European lithosphere dynamics. Geol Soc London Memoirs 32:191-206

Huismans RS, Bertotti D, Ciulavu D, Sanders CAE, Cloetingh S, Dinu C (1997) Structural evolution of the Transylvanian Basin (Romania): a sedimentary basin in the bend of the Carpathians. Tectonophysics 272:249-268

Hurford AJ, Green PF (1983) The zeta age calibration of fission-track dating. Chem Geol 41:285-317
Ilie M (1932) Harta geologica a muntilor Trascaului (Carte géologique des Monts Trascaului) 1: 55 000. Institutul geologic al Rômâniei Bucuresti. In: Anuarul institutului geologi al României 17

Ketcham R, Donelick R, Donelick M (2000) AFTSolve: a program for multi-kinetic modeling of apatite fission-track data. Geol Materials Res 1:1-32

Ketcham R, Carter A, Donelick RA, Barbarand J, Hurford AJ (2007) Improved modeling of fission-track annealing in apatite. Am Mineral 92:799-810

Kounov A, Seward D, Burg J-P, Bernoulli D, Ivanov Z, Handler R (2010) Geochronological and structural constraints on the Cretaceous thermotectonic evolution of the Kraishte zone (Western Bulgaria). Tectonics 29:TC2002. doi:10.1029/2009TC002509

Kräutner HG (1993) Pre-Alpine evolution in the southern Carpathians and adjacent areas. Geol Carpathica 44:203-212

Krézsek C, Bally A (2006) The Transylvanian Basin (Romania) and its relation to the Carpathian fold and thrust belt: insights in gravitational salt tectonics. Mar Petrol Geol 23:405-442

Laslett GM, Green PF, Duddy IR, Gleadow AJW (1987) Thermal annealing of fission track in apatite, 2. A quantitative analysis. Chem Geol 65:1-13

Ianovici V, Borcos M, Bleahu M, Patrulius D, Lupu, M, Dimitrescu R, Savu H (1976) Geologia Muntilor Apuseni. ed. Acad. RSR, Bucuresti, pp 631

Lupu M (1983) The Mesozoic history of the South Apuseni Mountains. Anuarul Institutului de Geologie şi Geofizică $60: 115-124$

Lupu M, Borcos M, Dimian M, Lupu D, Dimitrescu R (1967) Geological Map of Romania, scale 1:200 000, sheet Turda. Com Stat Geol, Bucuresti

Lupu M, Antonescu E, Avram E, Dumitrica P, Nicolae I (1995) Comments on the age of some ophiolites from the north Drocea Mts. Rom J Tectonics Reg Geol 76:21-25

Marton E, Tischler M, Csontos L, Fügenschuh B, Schmid SM (2007) The contact zone between the ALCAPA and Tisza-Dacia megatectonic units of Northern Romania in the light of new paleomagnetic data. Swiss J Geosci 100:109-124

Matenco L, Krézsek C, Merten S, Schmid S, Cloetingh S, Andriessen P (2010) Characteristics of collisional orogens with low topographic build-up: an example from the Carpathians. Terra Nova 22:155-165

McDougall I, Harrison TM (1999) Geochronology and Thermochronology by the ${ }^{40} \mathrm{Ar} /{ }^{39} \mathrm{Ar}$ Method, 2nd edn. Oxford University Press, New York, p 269

Merten S, Matenco L, Foeken JPT, Andriessen PAM (2011) Towards understanding the post-collisional evolution of an orogen influenced by convergence at adjacent plate margins: Late Cretaceous-Tertiary thermo-tectonic history of the Apuseni Mountains. Tectonics 30: TC6008. doi:10.1029/2011TC002887

Nicolae I, Saccani E (2003) Petrology and geochemistry of the Late Jurassic calc-alkaline series associated to Middle Jurassic ophiolites in the South Apuseni Mountains (Romania). Schweiz Mineral Petrogr Mitt 83:81-96

Nicolae I, Soroiu M, Bonhomme GM (1992) Ages K-Ar de quelques ophiolites des Monts Apuseni du Sud et leur signification géologique (Roumanie). Géologie Alpine 68:77-88

Pană D (1998) Petrogenesis and tectonics of the basement rocks of the Apuseni Mountains: significance for the Alpine tectonics of the Carpathian-Pannonian region. $\mathrm{PhD}$ thesis, University of Alberta

Pană D, Erdmer P (1994) Alpine crustal shear zones and pre-Alpine basement terranes in the Romanian Carpathians and Apuseni Mountains. Geology 22:807-810

Pană D, Heaman L, Creaser R, Erdmer P (2002) Pre-alpine crust in the apuseni mountains, romania: insights from $\mathrm{Sm}-\mathrm{Nd}$ and $\mathrm{U}-\mathrm{Pb}$ data. J Geol 110:341-354 
Panaiotu C (1998) Paleomagnetic constraints on the geodynamic history of Romania. In: Ioane D (ed) Monograph of Southern Carpathians. Reports on Geodesy 7:205-216

Panaiotu C (1999) Paleomagnetic studies in Romania. Tectonophysics implications. $\mathrm{PhD}$ thesis. University of Bucharest (in Romanian), pp 265

Patrascu S (1993) Paleomagnetic study of some Neogene magmatic rocks from the Oas-Ignis_-Varatec-Tibles Mountains (Romania). Geophys J Int 113:215-224

Patrascu S, Bleahu M, Panaiotu C (1990) Tectonic implications of paleomagnetic research into Upper Cretaceous magmatic rocks in the Apuseni Mountains, Romania. Tectonophysics 180:309322

Pavelescu L, Pop G, Ailenei G, Ene I, Soroiu M, Popescu G (1975) $\mathrm{K}-\mathrm{Ar}$ age determinations from the Apuseni and Banat Mountains. Rev Roum Geophys 19:67-69

Pécskay Z, Edelstein O, Seghedi I, Szakács A, Kovacs M, Crihan M, Bernad A (1995) K-Ar datings of the Neogene-Quaternary calcalkaline volcanic rocks in Romania. Acta Vulcanol 7:53-63

Proust JN, Hosu A (1996) Sequence stratigraphy and Paleogene tectonic evolution of the Transylvanian Basin (Romania, eastern Europe). Sed Geol 105:117-140

Rădulescu DP, Săndulescu M (1973) The plate tectonics concept and the geological structure of the Carpathians. Tectonophysics 16:155-161

Roşu E, Pécskay Z, Stefan A, Popescu G, Panaiotu C, Panaiotu CE (1997) The evolution of the Neogene Volcanism in the Apuseni Mountains (Romania): constraints from new K-Ar data. Geol Carpathica 48:353-359

Roşu E, Panaiotu C, Pécskay Z, Panaiotu CE, Ivăşcanu PM (2000) Neogene magmatism in the Apuseni Mountains, Romania. Evolution and geochemical features. An Inst Geol Rom 72:71-72

Roşu E, Seghedi I, Downes H, Alderton D, Szakacs A, Pecskay Z, Panaiotu C, Nedelcu L (2004) Extension-related Miocene calcalkaline magmatism in the Apuseni Mountains, Romania: origin of magmas. Schweiz Min Petrograph Mitt 84:153-172

Saccani E, Nicolae I, Tassinari R (2001) Tectonomagmatic setting of the Jurassic ophiolites from the South Apuseni Mountains (Romania): petrological and geochemical evidence. Ofioliti 26:9-22

Săndulescu M (1984) Geotectonica României. Tehnică, Bucharest, p 450

Săndulescu M (1994) Overview on Romanian geology. 2. Alcapa congress field guidebook. Rom J Tectonics Reg Geol 75(2):3-15

Săndulescu M, Kräutner HG, Balintoni I, Russo-Săndulescu D, Micu M (1981) The structure of the East Carpathians. Guide Book to Excursion B1 of the Carpatho-Balkan Geological Association 12th Congress, Bucharest pp 1-92

Săsăran E (2005) Calcarele Jurasicului superior-Cretacicului inferior din Muntii Trascău. Unpublished $\mathrm{PhD}$ thesis, University Cluj-Napoca

Schmid SM, Benoulli D, Fügenschuh B, Matenco L, Schefer S, Schuster R, Tischler M, Ustaszewski K (2008) The AlpineCarpathian-Dinaridic orogenic system: correlation and evolution of tectonic units. Swiss J Geosci 101:139-183
Schuller V (2004) Evolution and geodynamic significance of the Upper Cretaceous Gosau basin in the Apuseni Mountains (Romania). Tübinger Geowissenschaftliche Arbeiten Reihe A 70, pp 112

Schuller V, Frisch W (2006) Heavy mineral provenance and paleocurrent data of the Upper Cretaceous Gosau succession of the Apuseni Mountains (Romania). Geol Carpathica 57:29-39

Schuller V, Frisch W, Danisik M, Dunkl I, Melinte MC (2009) Upper Cretaceous Gosau deposits of the Apuseni Mountains (Romania) - similarities and differences to the Eastern Alps. Aus J Earth Sci 102:133-145

Soroiu M, Popescu G, Kapser U, Dimitrescu R (1969) Contributions preliminaires a la geologie des massifs cristallins des Monts Apuseni. Ann Stiintifice Univ Iasi Sect IIb (Geol) 15:25-33

Stewart RJ, Brandon MT (2004) Detrital zircon fission-track ages for the "Hoh Formation": implications for late Cenozoic evolution of the Cascadia subduction wedge. Geol Soc Am Bul 116:60-75

Tagami $T$ (2005) Zircon Fission-Track Thermochronology and applications to Fault Studies. Rev Mineral Geochem 58:95-122

Tagami T, Dumitru TA (1996) Provenance and history of the Franciscan accretionary complex: constraints from zircon fission track thermochronology. J Geophys Res 101:8345-8355

Tagami T, Galbraith RF, Yamada R, Laslett GM (1998) Revised annealing kinetics of fission tracks in zircon and geological implications. In: Van den Haute P, de Corte F (eds) Advances in fission-track geochronology. Kluwer, Dordrecht, pp 99-114

Tischler M, Gröger HR, Fügenschuh B, Schmid SM (2007) Miocene tectonics of the Maramures area (Northern Romania): implications for the Mid-Hungarian fault zone. Int J Earth Sci (Geol. Rundschau) 96:473-496

Ustaszewski K, Schmid SM, Fügenschuh B, Tischler M, Kissling E, Spakman W (2008) A map-view restoration of the AlpineCarpathian-Dinaridic system for the Early Miocene. Swiss J Geosci 101:273-294

Villa IM, Hermann J, Müntener O, Trommsdorff V (2000) ${ }^{39} \mathrm{Ar}-{ }^{40} \mathrm{Ar}$ dating of multiply zoned amphibole generations (Malenco, Italian Alps). Contrib Mineral Petrol 140:363-381

von Cotta B (1864) Erzlagerstatten im Banat und in Serbien. W. Braumuller, Wien, p 108

von Quadt A, Moritz R, Peytcheva I, Heinrich CA (2005) 3: geochronology and geodynamics of Late Cretaceous magmatism and $\mathrm{Cu}-\mathrm{Au}$ mineralization in the Panagyurishte region of the Apuseni-Banat-Timok-Srednogorie belt, Bulgaria. Ore Geol Rev 27:95-126

Willingshofer E, Neubauer F, Cloetingh S (1999) The significance of Gosau-type basins for the Late Cretaceous tectonic history of the Alpine-Carpathian Belt. Phys Chem Earth 24:687-695

Yamada R, Tagami T, Nishimura S, Ito H (1995) Annealing kinetics of fission tracks in zircon: an experimental study. Chem Geol 122:249-258

Zimmerman A, Stein HJ, Hannah JL, Koželj D, Bogdanov K, Berza T (2008) Tectonic configuration of the Apuseni-Banat-TimokSrednogorie belt, Balkans-South Carpathians, constrained by high precision Re-Os molybdenite ages. Mineral Deposita 43:1-21 